\title{
An Eco-linguistic Account of Press Real Estate Advertisements in Egypt
}

\author{
Rehab Farouk Gad \\ Lecturer of Linguistics \\ Mansoura University \\ Faculty of Arts \\ Department of English
}




\section{Abstract}

Advertising is an act of communication where readers are driven into a certain reaction mainly to the profit of the advertisers. Recently, research has witnessed an increase in demand to highlight the way language and ecology can be applied to over-lapping concerns; this has paved the way for research into ecolinguistics (a challenge to the $20^{\text {th }}$ century linguistics). Hence, the present paper focuses on the analysis of real estate advertisements as shown in print media. Data is based on real estate advertisements displayed in two Egyptian newspapers: AlWaseet "The medium", a free weekly advertising newspaper, and Al-Ahraam "The Pyramids", the most popular local newspaper in Egypt. The study carries out a linguistic analysis of these advertisements and their close relation to the eco system in Egypt. The theoretical framework within which this study is conducted is based on Halliday (1990), Weinrich (1990), fill (1998), and Armstrong (2010). A corpus of 39 advertisements was collected over a one month period starting from Friday the $6^{\text {th }}$ of April, 2018 to Friday the $27^{\text {th }}$ of April, 2018. The study aims to find out the prominent elements in these advertisements and how the ecological variation in Egypt induces a variation of linguistic patterns of real estate advertisements. The main focus is on investigating the ecological contexts in which these advertisements are embedded. The paper is divided as follows: section (1) introduces the topic; section (2) reviews some relevant literature on the language of advertising; section (3) discusses the main approaches of eco-linguistics. Data is described and analyzed in section (4) and section (5) sums up the main results and recommendation of the study.

Keywords: ecolinguistics; ecological variation; ambiguity; micro and macro analysis of data; quasi-experimental approach 
ملخص البحث

يعتبر الاعلان وسيلة للتواصل حيث يدفع بالقراء نحو ردة فعل معينة غالبا ما تكون في صالح

المعلن ، و مؤخرا فقد شهد البحث العلمي طلبا متز ايدا لإلقاء الضوء على اذدواجية التطبيقات التى تربط بين اللغة و الايكولوجيا ، و هذا قد مهد الطريق للبحث العلمي في مجال علم اللغة الايكولوجي متحديا لغويات القرن العشرين، و من هنا يهذف البحث الي تحليل الاعلانات العقارية في وسائل الاعلام المطبوعة، وقد نم تجميع البيانات من اعلانات عقارية تم نشرها في جريدتين مصريتين هما: الوسيط (جريدة اعلانية مجانية تصدر كل اسبوع) و الاهرام (واحدة من أثشر الصحف اليومية في مصر) ، و قد أجرت الدراسة تحليلا لغويا لهذه الاعلانات و القت الضوء على علاقتهم الوثيقة بالنظام الايكولوجي بمصر، تم تحليل البيانات من

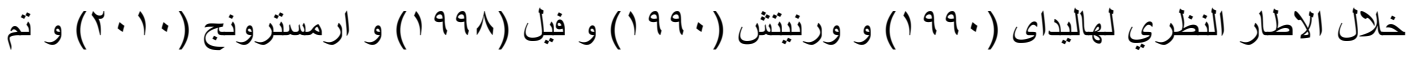
تجميع تسعة و ثلاثين اعلان على مدار شهر كامل بداية من يوم الجمعة (السادس من شهر ابريل لعام

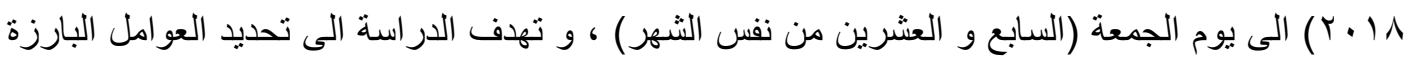
في هذه الاعلانات العقارية و توضيح كيف أحدث التتوع الايكولوجي بمصر الى تنوع الانماط اللغوية المستخدمة في الاعلانات العقارية، فموضع التركيز الرئيسي هنا هو دراسة السياق الايكولوجي الذي تعكسة لغة الاعلانات العقارية. و يقسم البحث على النمط النالي: الجزء الأول يعد مقدمة للبحث، أما الجزء الثاني فيلقي الضوء على الدراسات السابقة على لغة الاعلانات، و يناقش الجزء الثالث النهج الرئيسية لعلم اللغة الايكولوجي ، و يختص الجزء الر ابع بوصف و تحليل البيانات التي تم تجميعها، و يتم عرض أهم نتائج البحث في الجزء الخامس اضافة الى النتائج و التوصيات التي يقدمها البحث. 


\section{Introduction}

In literature, many studies were conducted on advertising linguistics: for example, Spitzer (1962) carried out a stylistic analysis of advertising whereas Henry (1963) investigated their truth conditional semantics. Leech (1966) proposed a descriptive linguistic analysis and a semiotic study was proposed by Barthes (1977). Vestergaard and Schroder (1985) conducted a sociolinguistic account of advertising. Since notions such as descriptive linguistics, sociolinguistics, and pragmatics (among others) have dramatically changed, this induced a change in the linguistic study of advertising.

The present study is motivated by the need to investigate the effects of the ecological variation in Egypt on the linguistic patterns and structures employed in real estate advertisements. The study is motivated by the interest to bridge the gap between Linguistics and ecology based on the analysis of empirical data. TV advertisements were not selected here to be linguistically analyzed since there is a considerable literature on it - e.g., Leech (1966). The print media selected for the purpose of the present study excluded billboard advertisements, posters displayed on buildings, walls and cars, as the focus here is on periodical publications of real estate advertisements. Language is manipulated so readers are engaged in cognitive processing of stimuli.

\section{Relevant literature on advertising language}

Linguistic studies have witnessed a dramatic change where all aspects of life can be examined from a linguistic perspective. Linguistics is applied for the analysis of advertising, so any change in linguistic theories induces a change in the study of advertising. One of the most interesting studies conducted on the language of advertisements is Goddard (1998). She defined advertisements as types of discourse that contribute significantly to the way people construct their own identities; commonly shared resources of language are manipulated in such a way 
that make them meaningful to people and hence influencing them. Goddard (1998) developed the notion of "unique selling proposition" to investigate how messages of advertisements are constructed from language. She argues that when spotting an advertisement, readers are interpreting paralanguage which encompasses aspects of communication that enhance people's verbal language in interactive contexts; examples of these aspects are body position, gesture, physical proximity, clothing, touch, and eye contact.

Though advertisements are generally understood as selling products, some are in fact selling ideas (e.g., gaining votes and passing legislation) and images; the following is an interesting example given by Goddard (1998, pp.8-9): The advertisement is designed in a photo story format to convey the tobacco advisory council's warning that selling tobacco to someone under 16 induces a $£ 400$ fine.

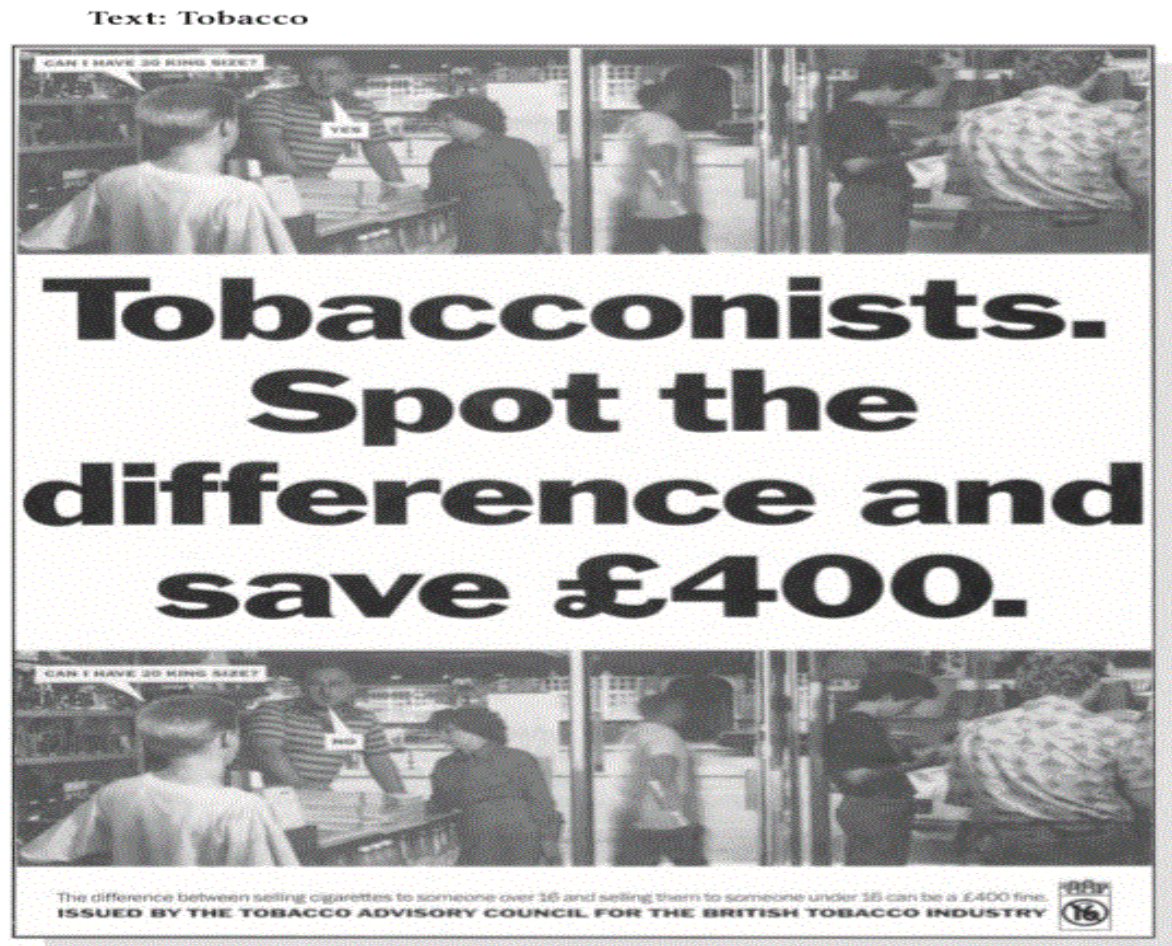

Armstrong (2010) investigated some principles of persuasive advertising. 
He argues that advertising aims at assisting all clients to feel a type of a positive change after buying the product advertised for. Persuasive language is manipulated so people feel safe and secure that a right decision was made; accordingly, profits and satisfaction are guaranteed. Armstrong (2010, pp. 25-26) proposes strategy as the main category of persuasion principles and divides it into the following four areas"

(1) Information is widely used in advertising. Consider an advertisement for a car: "This car has 8 cylinders and goes 200 miles per hour."

(2) Influence presents information in a way that motivates customers. For example, an advertisement using a scarcity principle might read: "This car is a limited edition—only 300 will be made."

(3) Emotion comes into play in the process of convincing customers who already have sufficient product information to make a purchase. "Feel the thrill of speed in this sports roadster."

(4) Mere exposure is applicable when an advertisement provides no information or emotion - only the product, brand name, or logo. "This concert was sponsored by Honda".

\section{Theoretical Framework of Eco-linguistics}

The present research attempts to conduct an ecolinguistic analysis of a selection of real estate advertisements in Egypt. The relation between language and ecology has raised a considerable attention in the literature. Kravchenko (2016, p.14) defines language as "a kind of socially driven behavior which contributes, in a quite definitive way, to the rich context of the human ecological niche, including texts, without which it cannot be understood". Fill (1998, p.5) defines ecolinguistics as "an interdisciplinary and interactive field of study in which the natural sciences (most specifically biological ecology) and the humanities 
(philology and philosophy) interrelated ....Since interrelation, networking, dialectics and diversity are key concepts of the discipline, uniformness is not regarded as a desirable aim in ecolinguistic theory and methodology".

Fill discusses two approaches of ecolinguistics: the first one is based on Haugen (1972) where ecology is interpreted metaphorically to refer to language(s) in environment. The second approach goes back to Halliday (1990) where ecology refers to "the role of language in the development and aggravation of environmental (and other societal) problems". Halliday (1992), cited in Fill (1998, p.10), claims that concepts such as growthism, sexism and classism are embodied and included in the grammar of any language. All language systems encompass and reflect our changing resources and our changing human nature. To underlie the relation between language and human experiences, Halliday (1990, p. 180) argues that "The history of language is part of human history; it is not some mysterious surrogate process that goes bubbling along on its own; this major upheavals in human history are also linguistic upheavals". Halliday's idea is that any changes, disorders, evolution in human history induce similar changes, disorders and evolution of language. In other words, the history of language is part of the human history. A change in the construction of reality induces a change in the construction of language. Accordingly, language reflects reality about the eco system and its featured phenomenon. The language that people use on daily basis is a development and a construction of reality. So, Halliday (1990, p. 194) proposes the following grammatical features that had evolved from human experiences.

(1) English distinguishes between two types of entity which exist in units: namely, countable versus uncountable nouns. Some uncountable nouns, such as soils refer to "kinds of". Since "air", "water" and "oil" are limitless natural resources, they are categorized ecolinguistically as uncountable.

(2) English Grammar identifies gradable traits of quality and quantity. 
Things are naturally described as (good or bad), (big or small), (long or short). The first items of each pair can be grouped as "positives" whereas the second items are "negatives". These words reflect human conception of traits.

(3) English Grammar reflects human perception of the entities and their capabilities of performing certain actions. Human beings are chosen as actors or doers whereas inanimate objects are acted upon except in certain metaphorized event where inanimate nature is represented as active doer.

(4) English Grammar makes a clear cut division of the pronoun system in terms of consciousness (he, she, they) versus unconsciousness (it) (p. 195).

The following are some illustrations of the idea based on Fill (1998, p. 10):

(1) languages natural resources are shown to be unlimited with the use of uncountable nouns or 'mass nouns' suggesting inexhaustibility (oil, energy, water, air etc.)

(2) in pairs of contrasts like big and small the 'growth word' is always the neutral term. It is always: how fast is the car (not how slow), how high is the building (not how low), how big is her income (not how small) etc.

(3) our languages are reluctant to admit non-human agents: 'what's that forest doing?' would be judged unacceptable by most speakers.

(4) the special position of the human species is expressed through the pro nominal system (he/she as special pronouns for humans, 'it' for all non-human beings) and through the exclusion of many collocations (think, know, believe, amiable, sympathetic etc.) for animals and plants. 


\section{Description and Analysis of Data}

\subsection{Description of Data}

In Egypt, all advertising companies attempt to influence the public through different types of media such as TV, magazines, the Internet, billboards, radio and direct mail. The data collected for the present study is press real estate advertisements. The reason why this type of data is selected is that real estate advertisements are closer to the eco system than other types like food, fashion home appliances and utilities. It is part of the Egyptian heritage that its people is attracted to and obsessed with land ownership as argued by Jamal Hemdan (1967). Ancient Egyptians considered land as a god and the River Nile as a spirit. This reflects the Egyptians' belief in centralism and dictatorship in decision making. Egypt used to be a vast desert where the River Nile was the only source of wealth and prosperity. This had placed the focus on the middle of the country; hence, land was, and is still, the ultimate possession. Jamal Hemdan (1967, p.212, v 2) comments on urban homogeneity in Egypt:

"if we considered villages and towns, as works of man, or if we considered the so

called cultural immobilia that reflects direct and concrete interaction between man

and environment or reflects a geographical reaction to man's activities, we would not

mistake the unity of base homogeneity."

Fakhry (2012, p. 27) discusses the nature of land in Egypt. He notes that the history of any nation is closely related to the nature of its land. He adds that nature of land had great impact on Egyptian civilization and hence fostered its development. This impact is still felt today and is shaping the development of historical events. Egyptians feel safe and secure if their money is given up in return 
of a piece of land or a house, rather than a factory or a workshop. Egyptians are aware that large profits can be gained by buying, selling or owning real estate properties. For them, such ownership is a risk-free saving policy.

In this study, real estate advertisements are classified into four main types as indicated by the following table:

Table (1): Types of real estate advertisements

\begin{tabular}{|l|l|}
\hline Type 1 & Public sector advertisements \\
\hline Type 2 & Private sector advertisements \\
\hline Type 3 & Public- private partnership advertisements \\
\hline Type 4 & Classified advertisements \\
\hline
\end{tabular}

\subsection{Analysis of Data}

In this paper, the word product will be used to refer to real estate properties following Armstrong (2010, p. 20) who argues that product applies to the features of a good or service, in addition to its image, price, method of distribution, support, and guarantees. Looking at real estate advertisements, some questions arise:

- What is being advertised?

- Who is being addressed?

In this study, these questions will be answered as part of a micro and macro analysis of data; each type of analysis is tackled separately.

\subsubsection{Micro Analysis of Data}

At the micro level, texts are analyzed where real estate advertisements can be viewed as a type of multidimensional commercial texts; these dimensions are environmental, social, financial and economic as seen below:

\section{(a) The Environmental Dimension}

To start with the environmental dimension of the real estate advertisements under investigation, we need to refer to the role of agency in environmental texts 
following Fill (1998, p.8). Ecolinguistic research differs in handling serious environmental issues: pollution being an example. For example, Gerbig (1993) conducted a study on ozone depletion where both the community and the consumer are taken to be responsible for such an environmental problem; agency responsibility is assigned to individuals. Gerbig (1993, p. 63) argues that people's behavior, following industrialization and globalization, contributes to the emergence of this environmental problem as illustrated by the following two examples:

(i) Damage to the ozone layer will increase cases of skin cancer ... (environmental group: transitive)

(ii) $\quad \ldots$. cases of non-malignant skin cancer have been increasing over many years ... (industry group: ergative)

In (i), agency responsibility is assigned to all individuals or companies who cause the problem. In (ii), the focus is on the action itself rather that the implicit agent who causes such environmental problem as indicated by the use of the ergative 'focus is on the agent or the one doing the action'.

Alexander (1996) represented the idea of agent shift or agency responsibility in the analysis of NIREX (Nuclear Industry Radioactive Waste Executive) advertisements. In the following examples (based on Fill 1998, p. 8) agency is represented differently:

Agent shift:

(iii) "Britain produces radioactive waste every day" and "the safe disposal of our radioactive waste".

Agent deletion through passivization:

(iv) "Safety requirements in the world will have to be met". 
In Egypt, environmental changes have led to linguistic variation where advertising companies motivate people to enjoy the life of summer resorts all year long. Recently, Egypt has witnessed dramatic climate changes and meteorology ascribed these changes to some elements such as people's practices and the industrial advance (global warming) which is the most dangerous phenomenon causing a serious change of the atmosphere. To clarify the relation between environmental issues and linguistic variation, consider the following type-twoadvertisement (no.37 Appendix D, published in Al-Waseet "The Medium" on the $27^{\text {th }}$ of April, 2018):

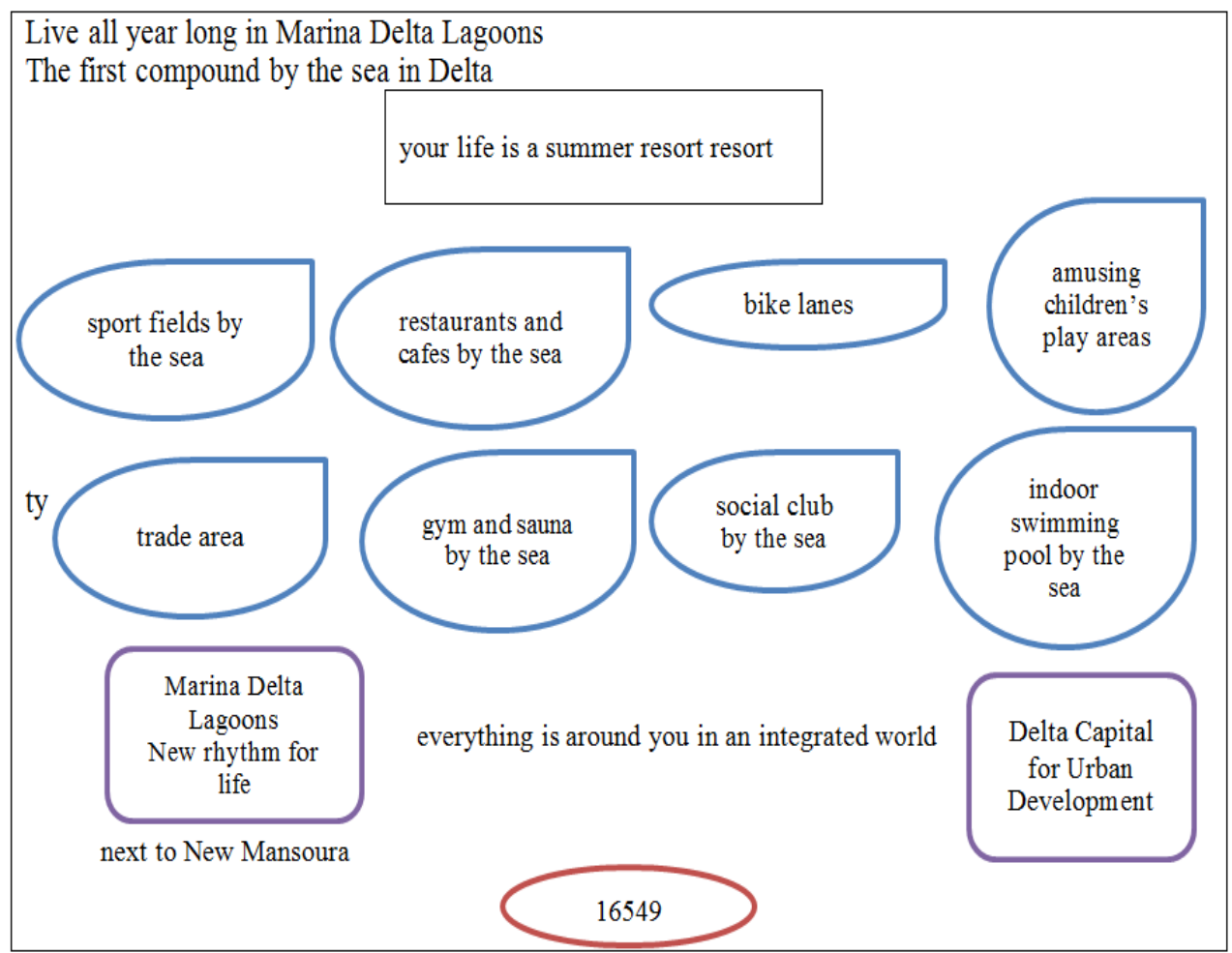

In the above advertisement, we notice the use of imperative structures such as عبش طول السنة في مارينا دلتا لاجونز 'live all year round in Marina Delta Lagoons' indicates that, opposite to Gerbig (1993), diffusing agency to all individuals disappear. According to this advertisement, agency responsibility (not for the environmental problem but for facing it) is shared between real estate holders and 
the customers/individuals. Instead of accusing people of being the main cause of environmental problems, people are called upon to go back to nature and move to a pollution- free area which is safer for their families' health. Individuals are invited and encouraged to move to environmentally friendly properties, advertised for by real estate holders, as a reaction to pollution and other environmental problems. The idea is more exemplified by the following advertisement displayed in AlAhram "The Pyramids" (no. 17, Appendix B, on the $13^{\text {th }}$ of April, 2018:

\begin{tabular}{|l|r|}
\hline $\begin{array}{l}\text { SERENIA } \\
\text { SIMPLY LIVING }\end{array}$ & Serenia \\
& Simply a beautiful life \\
A.W. & area starting \\
Sales branch: 61 Mohyee Aldeen Abo & from $123 \mathrm{~m}^{2}$ to \\
Al-Ez st. opposite to Al-Barak Bank & payment \\
\end{tabular}

In the above advertisement, sentence structures are made for manipulatory purposes. Adjectives such as beautiful and simple are used to enhance the advertisers' main aim which is to establish a physicalist picture of environment. We notice that almost all real estate advertisements of type two (private-sector) rely heavily on visual signs of green areas and other visual codes so readers can create and elicit meaning from all items embodied in the advertisement. The frequency of these signs and codes entails that people have become more aware of the environmental issues. Accordingly, it is not expected to encounter an advertisement for a pollution-free car as people will definitely question its credibility. We thus observe a radical change of the Egyptians 'perspective regarding their priorities. 


\section{(b) The economic and financial dimension}

Real estate advertisements are competing with each other to capture the attention of buyers; the idea is clarified by the two private- sector advertisements from Al-Waseet "The Medium" (Appendix C, no. 24, published on the $20^{\text {th }}$ of April, 2018) and Al- Ahraam "The Pyramids" (Appendix D, no. 39, published on the $27^{\text {th }}$ of April, 2018):

Al- Ahraam "The Pyramids"

Al-Waseet "The Medium"

THE CITY OF ODYSSIA

YOUR JOURNEY BEGINS...

NOW LAUNCHING ITS

FIRST CHAPTER

LUXURY APARTMENTS \& TOWNHOUSES IN

OSTAKBAL CITY

5\% DOWNPAYMENT

8 YEARS INSTALEMENTS

AL AHLY FOR REAL

ESTATE DEVELOPMENT SABBOUR

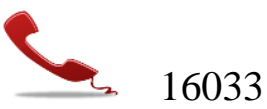

Company's headquarters: 290, $2^{\text {nd }}$ administrative district from Al-teseeni Al-ganoobi St.- New Cairo

Al-Mohandeseen branch: 106 Moyhee Al-Deeen Abu Al-Ez St. Al-Mohandeseen

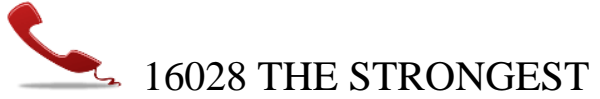

OFFER IN SUNSET AL-

NAKHEEL RESORT 2

$$
\text { RAS AL-BAR }
$$

Pay $10 \%$ and the rest on 4 years

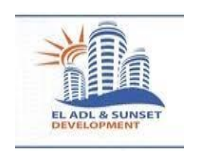

EL ADL SUNSET

DEVELOPMENTS

BOOK YOUR UNIT AND GET

YOUR TRIP- IN

\section{COLLABORATION WITH}

ELMAGEED FOR TOURISM

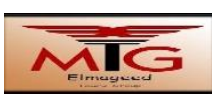

book your trip and get up to $50 \%$ discount on air plane tickets

01000580343-

01022732293-050/ 2338860 
Language used in the above two advertisements is both informative and persuasive. The superlative أقوى العروض 'the strongest offer', with its positive association of strength, is used euphemistically to mean 'the best offer/deal ever'. So investing money by buying a property in the new city is a short-run practice, but it is profitable on the long run. The advertiser here is doing something with language (as argued by Austin (1962) to deliver long-term benefits for both customers and sellers. Language is used here to achieve the three tasks of speech act (Searle, 1969):

Table (2): Speech act theory and real estate advertisements

\begin{tabular}{|l|l|l|}
\hline Speech Act & Example & Meaning \\
\hline $\begin{array}{l}\text { A locutionary act } \\
\text { (the meaning) }\end{array}$ & $\begin{array}{l}\text { THE STRONGEST } \\
\text { OFFER IN SUNSET }\end{array}$ & $\begin{array}{l}\text { One of the best offers } \\
\text { in Sunset }\end{array}$ \\
\cline { 1 - 1 } $\begin{array}{l}\text { an illocutionary act } \\
\text { (intention of the } \\
\text { speaker) }\end{array}$ & & $\begin{array}{l}\text { The intention of the } \\
\text { advertising company } \\
\text { is end up with the } \\
\text { reader booking one of } \\
\text { the advertised units }\end{array}$ \\
$\begin{array}{l}\text { A perlocutionary act } \\
\text { (the effect upon the } \\
\text { reader) }\end{array}$ & & $\begin{array}{l}\text { The reader uptakes the } \\
\text { offer }\end{array}$ \\
\hline
\end{tabular}

Now, we will consider the economical aspect of the real estate advertisements from a different perspective; it is tackled in relation to "ecology". So, in this paper, we claim that "ecology" and "economy" are two closely related concepts. This idea is discussed by Weinrich (1990, p. 94); he argues that ecologists and economists cooperate and act as a householder who works for the stability and security of people living in the same house. For Weinrich, "ecology 
does not invalidate economy", it induces some changes in the economic thinking and introduces concepts such as long-term vision, caution and considerations. Weinrich (1990, p. 94) proposes the following four parameters of ecological thinking:

(1) Taking into account not just system-internal factors but to an equal extent system-external environmental conditions;

(2) Paying attention to these problems that arise from the one-sidedness of monoculture;

(3) The perspective of limited resources with regard to both nature and human working capacity;

(4) A certain long-distance vision for future perspectives.

Weinrich (1990, p. 95) argues that linguistic signs are positive indication of both economic success and social power. Linguistic systems are to be analyzed within the social environment of this system. He claims that ecological analysis has to be based on consideration of monoculture. In other words, ecological analysis considers all variables in a certain culture or what is referred to as monoculture.

Weinrich (1990, P. 99) views Grice's (1967) conversational maxims as a logical outcome of the linguistic economy and linguistic ecology interface; violation of the conversational maxims is "as a sign of ecological progress, when the perspective of short-term saving and short-term effort is reduced in its validity in favor of the prospect of the desired continuation of a dialogue in the future- a classic instance of the economy-ecology problem ". To see whether the ecolinguistic account of press real estate advertisements proposed in this paper is in accordance with Weinrich's idea that linguistic economy diverges from linguistic ecology, let us consider the following table: 
Table (3): Grice's Conversational Maxims

\begin{tabular}{|c|c|}
\hline Grice's maxim & $\begin{array}{l}\text { Examples from real estate advertisements } \\
\text { published in Al-Ahraam "The } \\
\text { Pyramids": 20-4-2018 }\end{array}$ \\
\hline $\begin{array}{l}\text { (1) The maxim of } \\
\text { quantity } \\
\text { Make your contribution as } \\
\text { informative as is required } \\
\text { Or } \\
\text { Speak economically! }\end{array}$ & $\begin{array}{l}\text { (i) Zaher City (Appendix C, } \\
\text { no. 32) } \\
\text { In Nasr City- Hassan Al-Ma'moun St. } \\
\text { after Majsed Al-Salam } \\
\text { Booking for second phase is opened: } \\
\text { booking payment 5\%. Contract payment } \\
\text { 15\%. } 5 \text { years payment plan with } 0 \\
\text { interests Receipt within } 24 \text { months, areas } \\
\text { from } 125 \text { m to 191m, overlooking } 80 \text { m } \\
\text { street. Available in phase one: limited } \\
\text { number of units with complete facilities } \\
\text { "immediate receipt" and shops with } \\
\text { commercial license "immediate receipt" } \\
\text { 50\% down payment, the rest paid in } 24 \\
\text { months installments with } 0 \text { interests. } \\
\text { Owner: Misr Express Company for urban } \\
\text { and Trade Development (Al-Zaher), a } \\
\text { member of Magdy Zaher and Andrew } \\
\text { Magdy Zaher Group } \\
\text { Company Headquarters: } 5 \text { Al-Mesaha St } \\
\text { - Al-Dokki-above Metro Market } \\
\text { Viewing at location: 01202653537/ } \\
\text { 01005204835 }\end{array}$ \\
\hline
\end{tabular}




\begin{tabular}{|c|c|}
\hline $\begin{array}{l}\text { (2) The maxim of } \\
\text { manner } \\
\text { Be brief! avoid unnecessary } \\
\text { prolixity! } \\
\text { Or } \\
\text { Don't say more than is } \\
\text { strictly necessary }\end{array}$ & 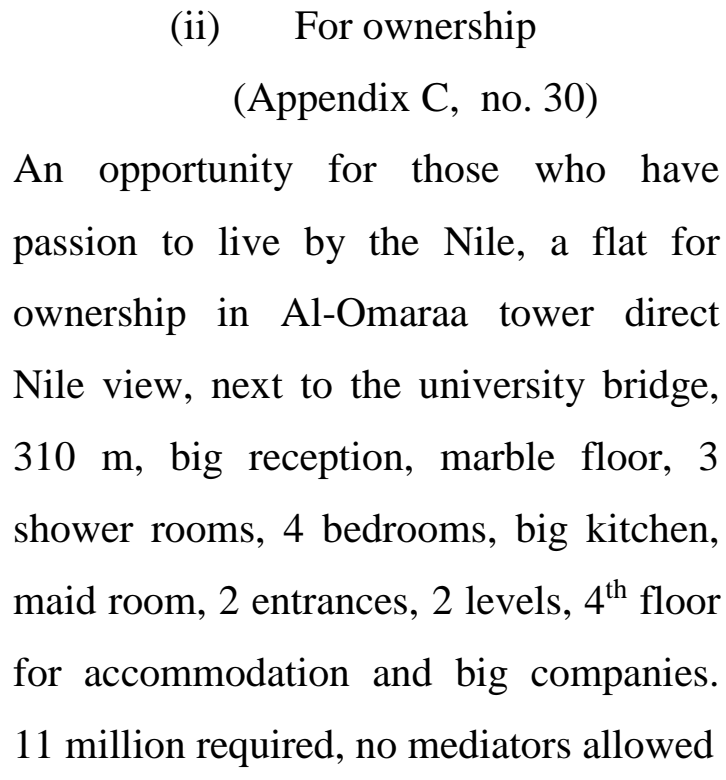 \\
\hline $\begin{array}{l}\text { (3) The maxim of } \\
\text { quality } \\
\text { where one tries to be } \\
\text { truthful, and does not give } \\
\text { information that is false or } \\
\text { that is not supported by } \\
\text { evidence }\end{array}$ & $\begin{array}{c}\text { (iii) Al-Tawfeqiya for real } \\
\text { estate investment } \\
\text { (Appendix C, no. 29) } \\
\text { The strongest offers, take the opportunity, } \\
\text { possess in the most luxurious locations in } \\
\text { Al-Shrouk } \\
\text { Distinctive apartments } \\
01113313073\end{array}$ \\
\hline $\begin{array}{l}\text { (4) The maxim of } \\
\text { relation } \\
\text { where one tries to be } \\
\text { relevant, and says things } \\
\text { that are pertinent to the } \\
\text { discussion }\end{array}$ & $\begin{array}{c}\text { (iv) wanted for rent } \\
\text { (Appendix C, no. 31) } \\
\text { two farm lands good for poultry farming } \\
\text { in Al-Ismailia or its suburbs, with one } \\
\text { condition of being far from any poultry } \\
\text { farm lands or residential areas, total space } \\
\text { not less than square kilometers } \\
\text { the } 1^{\text {st: }} \text { about } 4500 \mathrm{~m} 2 \\
\text { the } 2^{\text {nd. }} \text { about } 2250 \mathrm{~m} 2\end{array}$ \\
\hline
\end{tabular}


proposals sent to box: 2655 Ataba - Code

\section{1}

Looking at the language used by advertisers in the advertisements displayed in the above table, it is interesting to note that Grice's conversational maxims are not met: in (i), the advertising company is stressing the idea that customers will not pay extra interest; it is an interest- free purchase as indicated by the two italicized sentences in the advertisement. Another example of the violation of Grice's maxim of quantity in (i) is the repetition of the underlined noun phrase "immediate receipt". In (ii), the maxim of manner is not met as the advertiser here insists on giving more unnecessary details regarding the internal division of the apartment and all possible usages of the rooms. In (iii), distinctive apartments are advertised for though it is not clear whether they are distinctive in terms of location, space, price, facilities etc. Hence, we can argue that the maxim of quality is lacking here. Finally, in (iv), a poultry farm is required with the condition that it has to be far from other farms and residential areas. The advertiser here failed to establish a relation between what is required and what is rejected. The language manipulated in this advertisement is confusing the reader of whether it is preferable for poultry farms to be far from other farms or at the outskirts of the town. In sum, these advertisements can be taken as an indication of ecological progress and we can conclude, following Weinrich (1990), that linguistic ecology and linguistic economy are inseparable.

\section{(c) The social dimension}

This section focuses on investigating how real estate advertisements reflect social reality in Egypt. Tracing the type of real estate product advertised in one week (e.g., the $13^{\text {th }}$ of April), we find that advertisements for available pieces of land that can be used for investment purposes (e.g., to build factories or workshops) occupy a small percentage of the total number of other real estate advertisements, below is an example (see Appendix B, ad no. 21): 


\section{POLARIS \\ Polaris Al Zamil Industrial Park}

CS DO

sine

in the heart of the industrial area in 6 October City

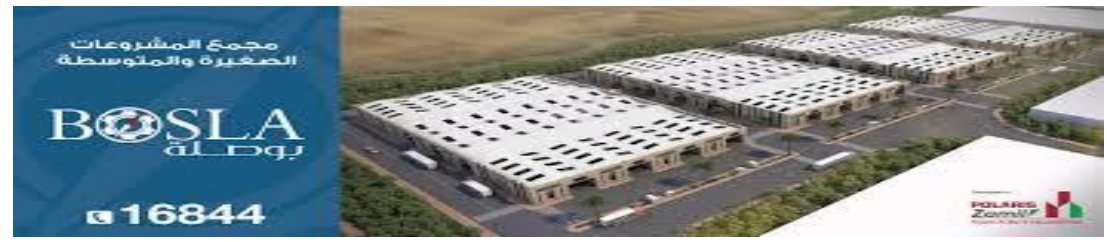

Ready Industrial Warehouse units delivering ready for operation

Areas starts from $500 \mathrm{~m}$

Flexible payment terms

Financing the purchase of units in cooperation with the National Bank of Egypt, under the initiative of the Central Bank of Egypt to support small and medium enterprises

Terms and Conditions Apply

6 October City - North Expansions- Developers area - area no.1 - administrative building of Polaris Industrial Park.

license no. 460, issued on 26/10/2017 from General Board of Industrial Development. 16844

The italicized text is the actual structures appeared in the advertisement; we notice that it is of type three (Public- private partnership advertisement): National Bank of Egypt and Polaris Zamil. Looking at this advertisement from an ecolinguistc perspective, some ideologies, social realities and ways of life controlling Egyptians are reflected as follows:

1. people look for easier ways to invest their money rather than to make money. 
2. People are attracted to ready-made projects.

3. Properties advertised for appear luxurious and easy-to-obtain.

4. Advertising companies make strong arguments in their advertisements.

5. Secure investment opportunities are obtained through corporation with the government.

Goddard (1998, p. 7) argues that "advertisements often have complex sets of addressers and addressees". In a single text, we can encounter a single voice addressing a certain class of people or different voices sending more than one message to more than one class of people; the idea is clarified by the advertisement (published in Al-Waseet "The Medium" (Appendix D, ad no37, on the $27^{\text {th }}$ of April, 2018) repeated below:

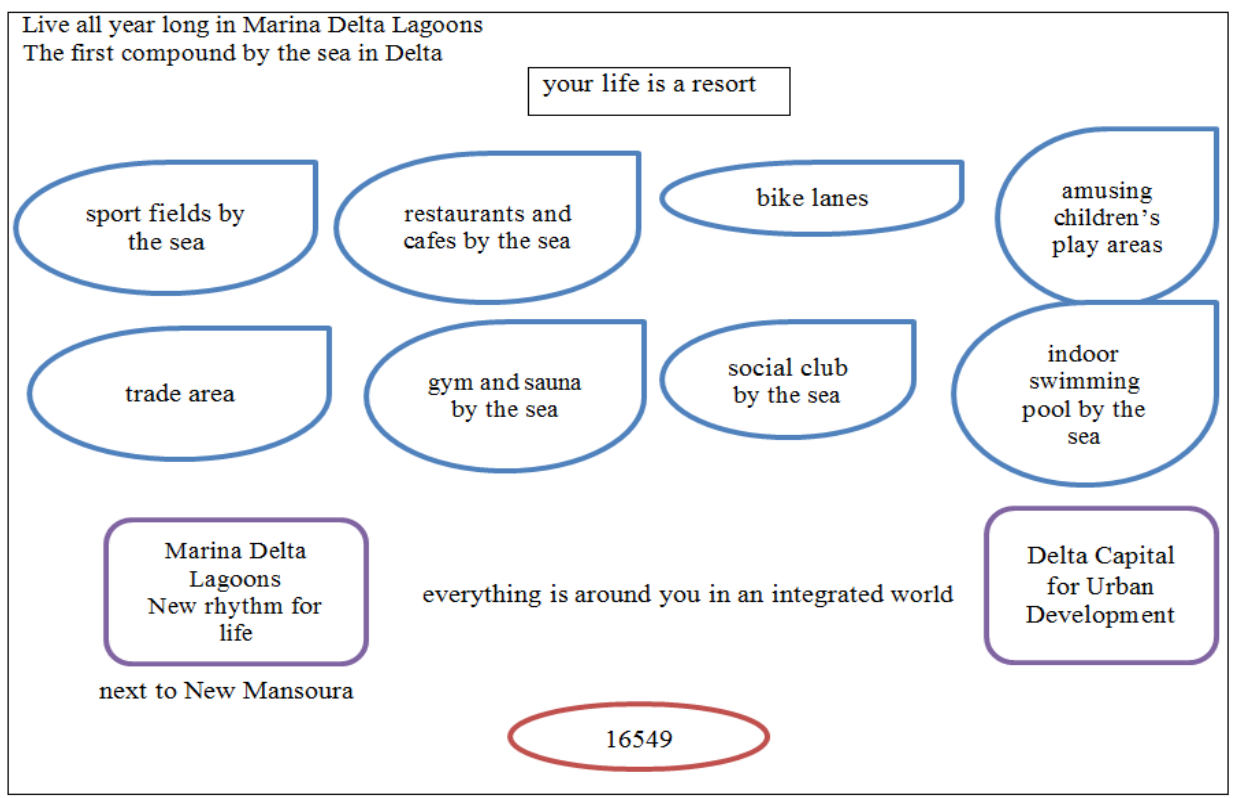

The main assumption here is that this advertisement attracts more than one group of people; lexical choices are made for manipulatory purposes; the idea is clarified by the following table:

Table (4): Lexical choices and target groups 


\begin{tabular}{|c|c|}
\hline 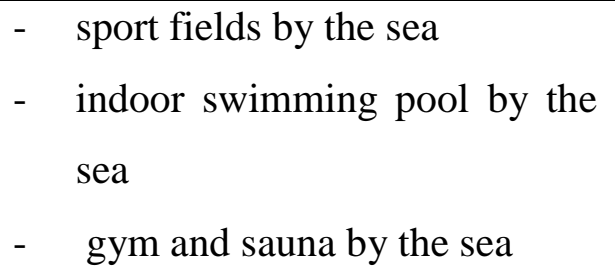 & athletes, young age groups \\
\hline $\begin{array}{l}\text { - restaurants and cafes by the } \\
\text { sea }\end{array}$ & all age groups (males and females) \\
\hline - $\quad$ trade area & businessmen and females \\
\hline - $\quad$ amusing children's play areas & children and mothers \\
\hline - $\quad$ bike lanes & athletes, teenagers, young age groups \\
\hline
\end{tabular}

So, we can argue that language employed in this advertisement highlights some social realities about the target readers. Only educated people will be attracted to structures such as حياتك مصيف 'your life is a summer resort'. Less educated, illiterate or middle class families will consider the price and payment schemes. Another important social reality reflected in real estate advertisements is that housing is one of the social problems bred by overpopulation in Egypt. Available places (e.g., rooms and halls) for conferences, seminars, workshops, talks, or cultural symposiums are never advertised for.

\section{(d) Attention seeking devices}

A common feature shared by all advertisements discussed in the above subsections is attention seeking devices employed by advertising copywriters. The following devices are ecologically driven:

1- Clear sky

2- Green areas

3- Security gates

4- Swimming pools

5- Open markets and cafes

Both visual signs and written language in a text are attention seeking 
devices that elicit quick response from the reader. Visual signs are visual codes which help readers create meaning from given items; visual signs of green areas and children riding bicycles are examples. Other devices such as sharing mutual interest with readers are also employed. For example in the following advertisement (published in Al-Waseet "The Medium" (Appendix A, ad no1, on the $6^{\text {th }}$ of April, 2018) reference to a famous celebration in Egypt (i.e., Easter) is encountered: 


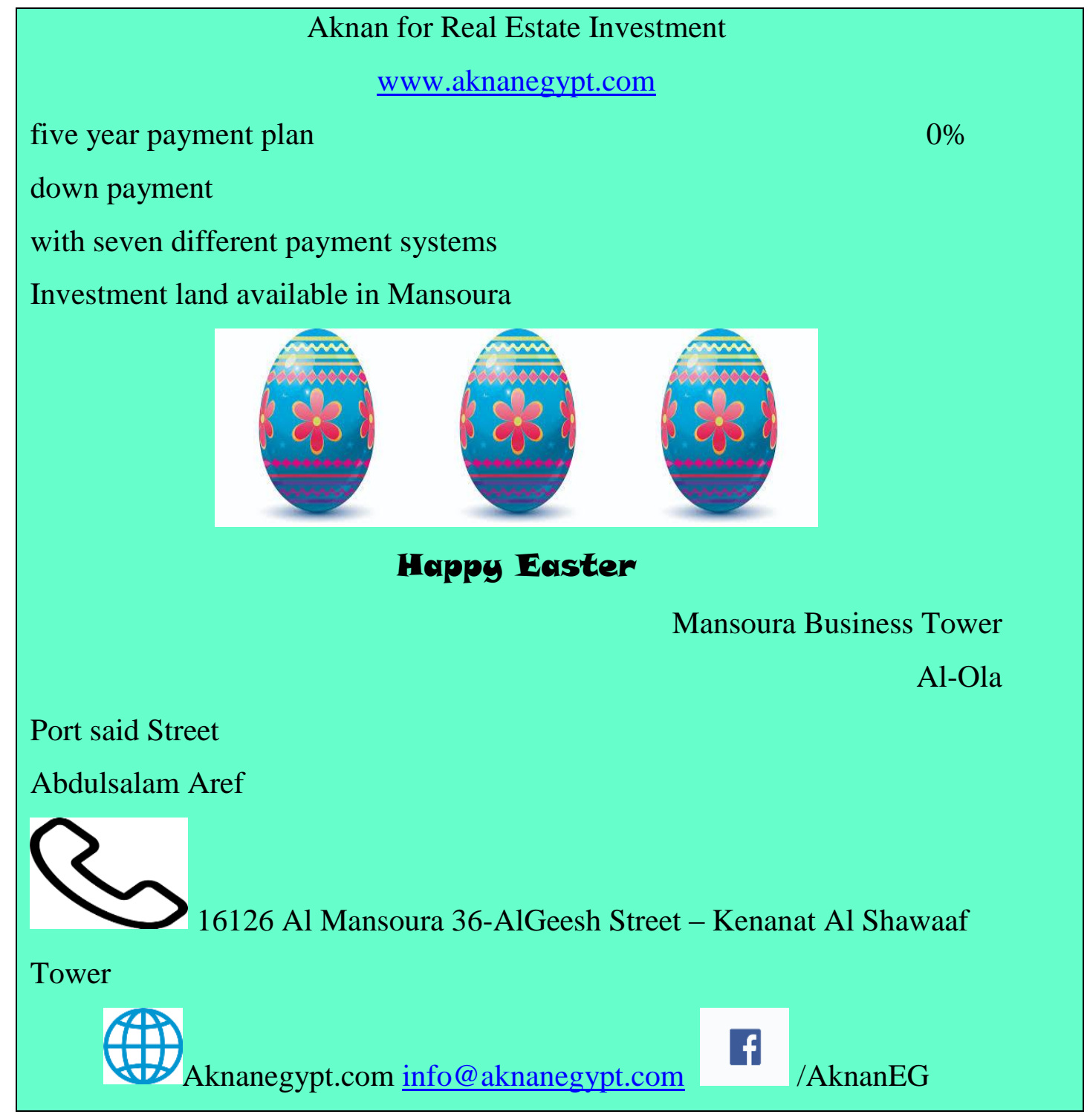

Advertising companies are aware of the fact that women are more attracted to visual signs than men and they are keener on planning their own finance; accordingly language implicitly addressing them is more accurate, more direct, less complicated and requires instant actions; all offers guarantee easy payment schemes with down payment. So, we can conclude that attention seeking devices highlight the gender dimension of real estate advertisements in Egypt.

\subsubsection{Macro Analysis of Data}

At the macro level, the whole discourse and its ecolinguistic implications are driven. Political implications can also be driven as these advertisements reflect 
the close relation between power and administration in Egypt. Egyptians are obsessed with bureaucracy and power. Now, consider the following advertisement (appeared in Al-Ahram "The Pyramids", Appendix A, ad no. 4, on the $6^{\text {th }}$ of April 2018):

\begin{tabular}{|c|c|}
\hline & Ministry of Public \\
\hline \multicolumn{2}{|l|}{ Enterprise } \\
\hline & Holding Company for Reconstruction \& Development \\
\hline & Heliopolis Company for Housing \& Development \\
\hline & Rental Offer of Show land \\
\hline & \& Children's park in Maryland Park \\
\hline & fixed period lease (seven years) in public auction \\
\hline & scheduled on Sunday 13-5-2018 \\
\hline & venue: \\
\hline & at Maryland Park, Al-Maehad Aleshtraki St, Heliopolis \\
\hline & total buildings area: approximately 1000,00 square meters \\
\hline & total land area: approximately 10615,00 square meters \\
\hline & for tourism \& leisure activities \\
\hline & (restaurants- cafes- children's park) \\
\hline & A statement of work with all details for 5000,00 EGP \\
\hline & (five thousand Egyptian pounds only) \\
\hline & Available at company rental sector \\
\hline & headquarters/ 28 Ibrahim Al-Laqany St.- Roksy- Heliopolis \\
\hline & Phone number: 22919424 - 22919428- 22919429 \\
\hline
\end{tabular}

The above advertisement is of type 3 (Public- private partnership). Heliopolis Company for Housing \& Development, which belongs to the private 
sector, is incorporating with a government body, which is the Ministry of Public Enterprise. The information included in this advertisement drives us to question about the type of relation between the public and the private sector; the question now is whether we can describe the public sector, represented by the Egyptian Government, as controlling, owning, or running the private sector. As no answer to this question can be provided, we conclude that the language of such a type of advertisement is ambiguous.

Ambiguity also highlights the language of type four (classified advertisements) as illustrated by the following three advertisements (appeared in Al-Ahram "The Pyramids" (Appendix A, ads no. 11- 14-12), on the $6^{\text {th }}$ of April 2018):

(a)

\begin{tabular}{|c|c|}
\hline $\begin{array}{l}\text { A great opportunity on } \\
\text { sale } \\
6 \text { acres of good quality } \\
\text { farming land in wild basin } \\
\text { area- Al-Aaly outskirt, } \\
\text { another 5acres and } 16 \\
\text { karats farming land+ } 4 \\
\text { karats of building land, } \\
\text { Ibyana outskirt in Motobas } \\
\text { town - Kafr AlSheikh } \\
\text { priority for payment made } \\
\text { in foreign currency } \\
\text { tele: 0100321982 } \\
\text { Email: } \\
\text { meeepro@yahoo.com }\end{array}$ & 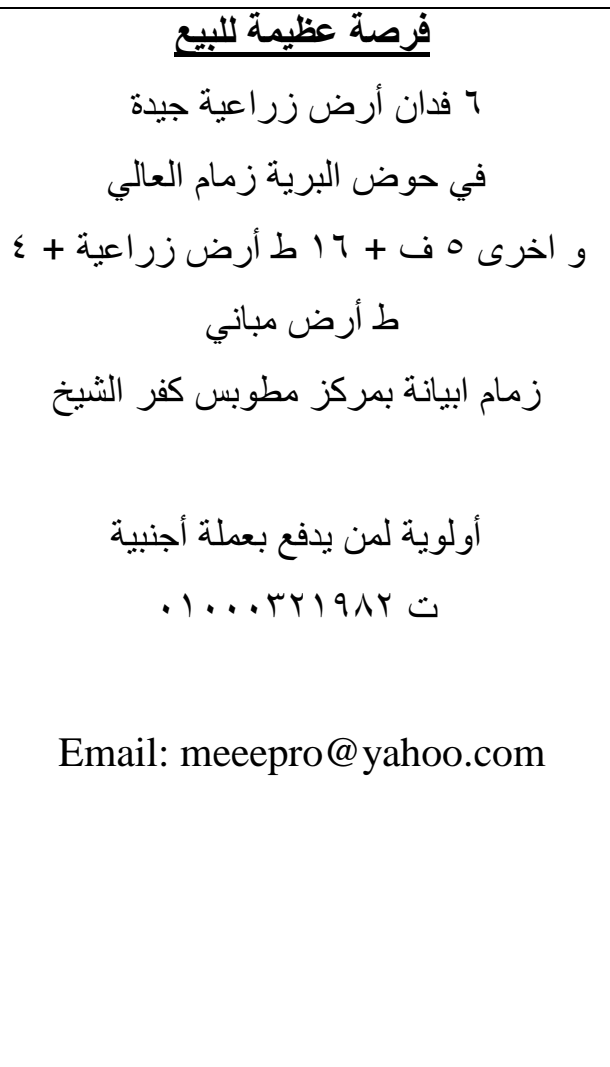 \\
\hline
\end{tabular}


(b)

\begin{tabular}{|c|c|}
\hline 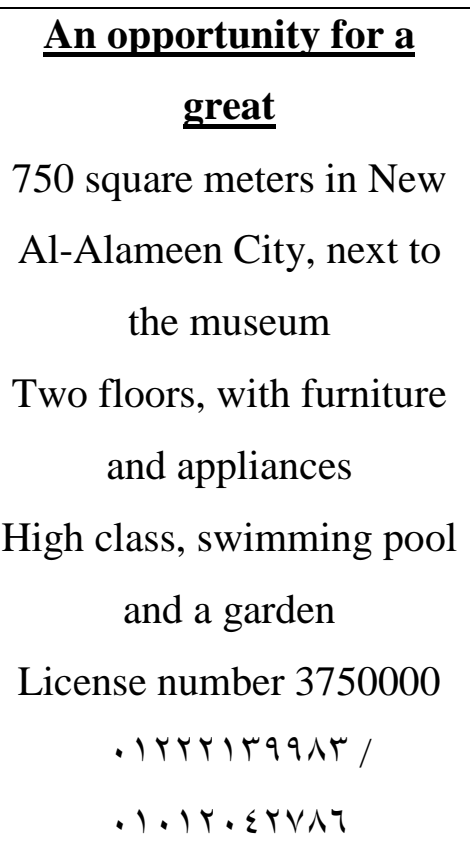 & 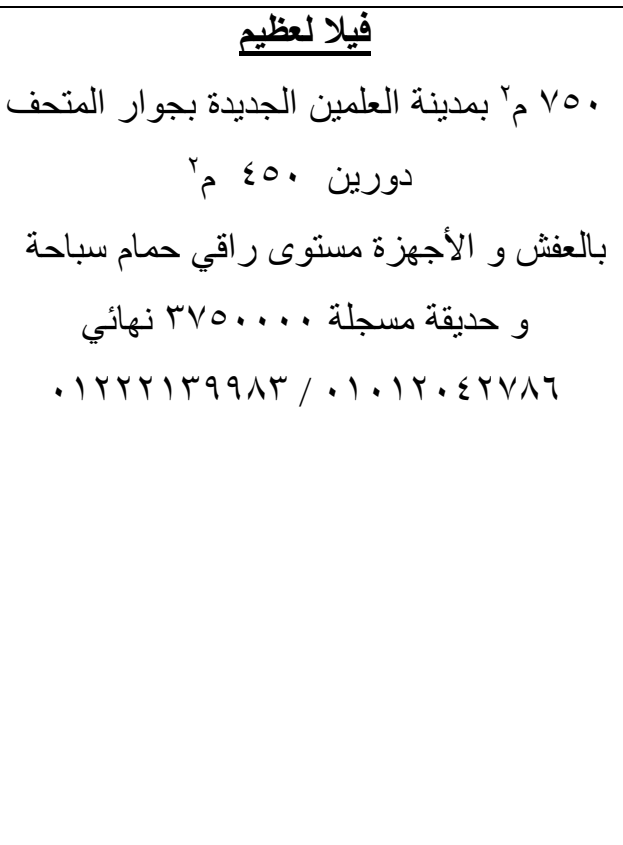 \\
\hline
\end{tabular}

(c)

\begin{tabular}{|c|c|}
\hline For the elite & للصفوة \\
\hline Villa in Costa Del Sol- Kilo & فيلا بمنتجع كوستا دول سول ك r \\
\hline 82 & أرض • 01- ـ نوم \\
\hline Land $510-4$ bedrooms + & + ريسبشن- 7 حمام \\
\hline reception, 6 shower rooms & ملحق للخدم r نر اس \\
\hline Butler's pantry - 2 terrace & حديقة \\
\hline Garden - Luxurious & فرش راقي بجميع الكماليات \\
\hline $\begin{array}{l}\text { furniture with all } \\
\text { supplements }\end{array}$ & $.1 \ldots 9 \ldots 9 \ldots$ \\
\hline Tele: $\cdot 1 \cdot 9 . \cdot 9 \ldots$ & \\
\hline
\end{tabular}

In analyzing the advertisements (a-c), a quasi-experimental approach is followed where two or more advertisements for the same product are compared (Armstrong 2010, p. 10). In advertisement (a), good quality farming land is being advertised in Motobas, a part of 
Kafr AlSheik governorate located at the north of Egypt. In spite of being a basically primitive countryside, language employed in the advertisement ascribed positive traits to it. For example, by saying that the advertised product is a good farming land, it implies that it can be sold at a reasonable price for those who would use it for building and it is a pollution free area. The advertising company here is not aware of who would be interested in the advertised product; however, farmers, contractors or investors might be targeted. For the advertising company, these three groups of customerw are the ideal readers.

In advertisement (b), a villa for a GREAT is being advertised. HIGH CLASS furniture and appliances are also available. Regarding the language manipulated in this advertisement, the following questions arise: what is the basis on which GREATNESS is assigned? Is it assigned based on wealth, fame, education, or social class? The adjective GREAT here is ambiguous as it lacks a specific reference. Language employed here implies that this advertisement is not addressed to all types of customers. It targets a specific social class of readers (e.g., wealthy readers who are after a high standard of living); this class will be referred to as intended readers.

Similarly, the property advertised for in (c) is luxurious with large number of rooms and a butler's pantry; hence, it can be argued that such advertisement is for intended readers as indicated by the word ELITE.

A surprising phenomenon that has recently appeared in real estate advertisements in Egypt is real estate exports; consider the following advertisement appeared on Al- Ahraam "The Pyramids" (Appendix A, ad no. 10) on the $6^{\text {th }}$ of April, 2018: 


\section{DUBAI}

INVESTEMNT

SHOW 2018

Global Building

Real Estate Marketing \& Development

more than 20 projects in Dubai

apartments ready for

immediate move in

starting from 4 million EGP

in Dubai Damak

Hills

luxurious villas in international golf community in Dubai

\section{6,990,000 EGP}

starting from 6 million EGP

reasons encouraging you to invest in Dubai

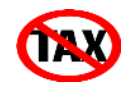

high rent revenues

stable currency

safe

environment luxurious life style

exempt from taxes

global

infrastructure

Exclusive Offers during the event

Please visit us on April 13, 14 and 15

Royal Maxim Palace Kempinski- $1^{\text {st }}$ settlement - Ring Road- New Cairo

From $3 \mathrm{pm}$ to $5 \mathrm{pm}$

For appointment, contact us via

01270100500/info@gp.com.eg 
A product is exported when sent from a country to another; however, real estate export involves selling green areas, clear sky, and pollutionfree environment to foreigners. So, real estate advertisements started using another language that propagates this idea as a source of foreign currency. Unreasonable and illogical language is encountered; this implies that people are willing to sell their environment and export it. This idea supports the initial claim of the present study that ecological variations foster and induce linguistic ones.

\section{Conclusion}

This research was carried out within the general framework of ecolinguistics principles. The present paper attempted to examine the language of real estate advertisments in Egypt within the perspectives of eco-linguistics. It proposed an eco-linguistic analysis of real estate advertisements as a construct used in discursive production of the life-world. Text corpora from newspapers were used to investigate the actual use of environmental vocabulary. The reason why real estate advertisements were selected here is that they are more related to the ecological system. Put is differently, linguistic variation exemplified in real estate advertisements is a logical outcome of the ecological variation witnessed in Egypt. Real estate advertisements are a type of environmental texts that reflect social and physical environment of Egyptians.

With the motive of financial gain, advertisers manipulate different linguistic structures to persuade the readers. By classifying these advertisements into four main types, we argue that each type is sending a message, not to all Egyptians, but to a certain group of people. For example, type one (private sector advertisement) addresses a group can be described as having:

- fair educational background

- financial resources sufficient to pay for installments

- fixed income

- perspective on the value of the advertised properties 
- saving plans

- a desire to change to a better environment and future

- risk- taking

Based on the analysis of the language employed in the selected corpora, the study finds out that real estate advertising companies, despite the occasional lack of an explicit reference, classify their readers into four main categories:

(1) intended/ target readers: the advertising company is aware of its readers

(2) ideal readers: the advertising company is not sure who will see its advertisement; however, the company believes that only a certain class of readers is likely to understand, evaluate and respond to it

(3) implied readers: advertisements are designed in the third voice so family and friends are invited.

(4) occasional readers: those who are just passing by; their response is not guaranteed.

(5) Unspecified readers: This category encompasses people with different educational, financial, and social backgrounds.

To conclude, based on the analysis drew upon data on 39 of press advertisements from Al-Waseet "The medium" and Al-Ahraam "The Pyramids" that had appeared in a period of one month, it was clear that written advertisements are competing with each other in our materialistic culture. The research findings can be summarized as follows:

(1) All types of real estate advertisements discussed above share one main linguistic feature which is AMBIGUITY.

(2) Some real estate advertisements reflect confusion between public and private sectors. 
(3) Attempts made by real estate advertising companies to classify their readers though linguistically implied.

The study recommends a more detailed comparative study based on real estate advertisements in different environments other than Egypt, so universal features of this type of advertising language and a specialized thesaurus can be proposed. 


\section{Appendices}

Appendix (A): Week one ( $6^{\text {th }}$ of April 2018)

Al Waseet"The Medium"

Ad (1)

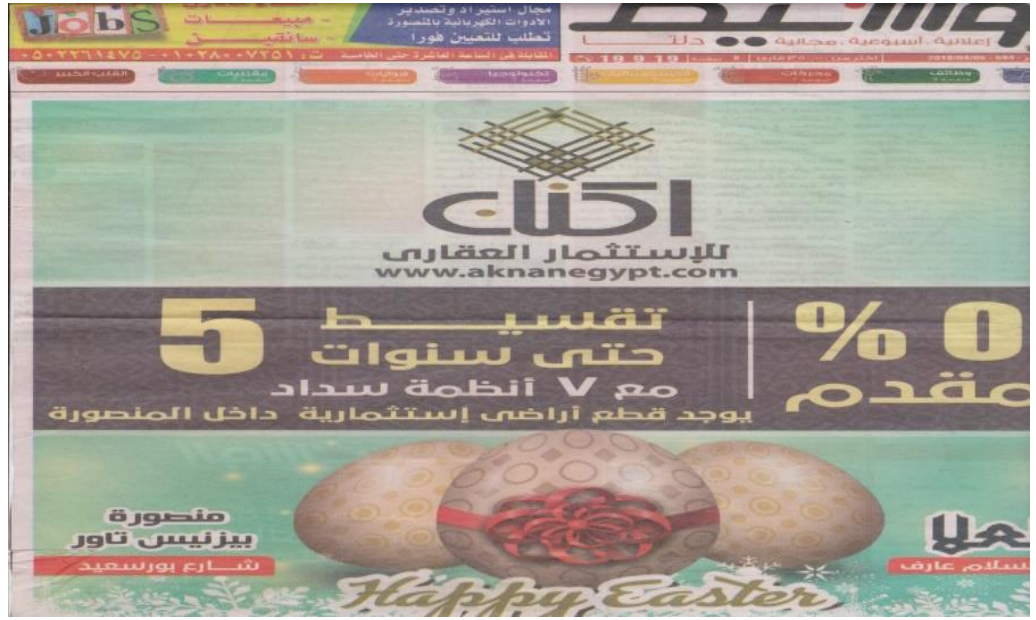

Ad (2)

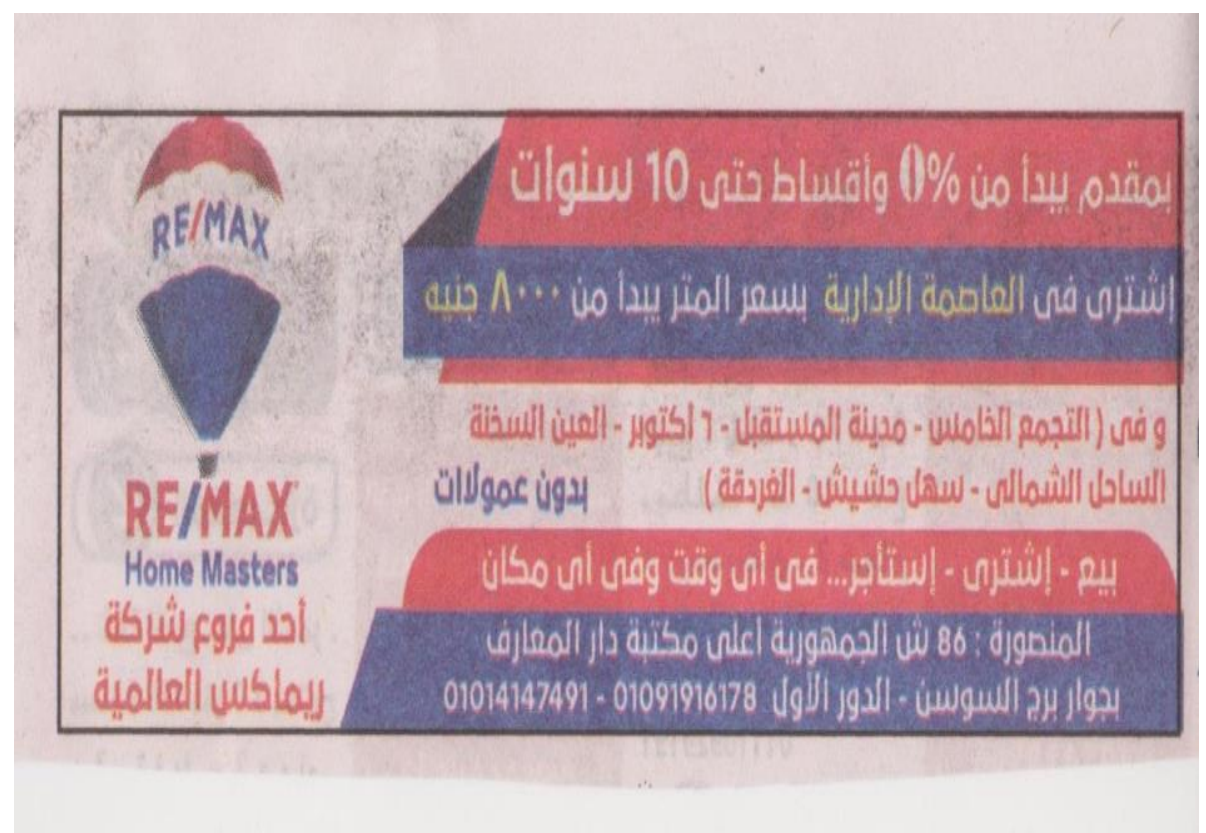




\section{Al-Ahraam "The Pyramids"}

\section{Ad (3)}

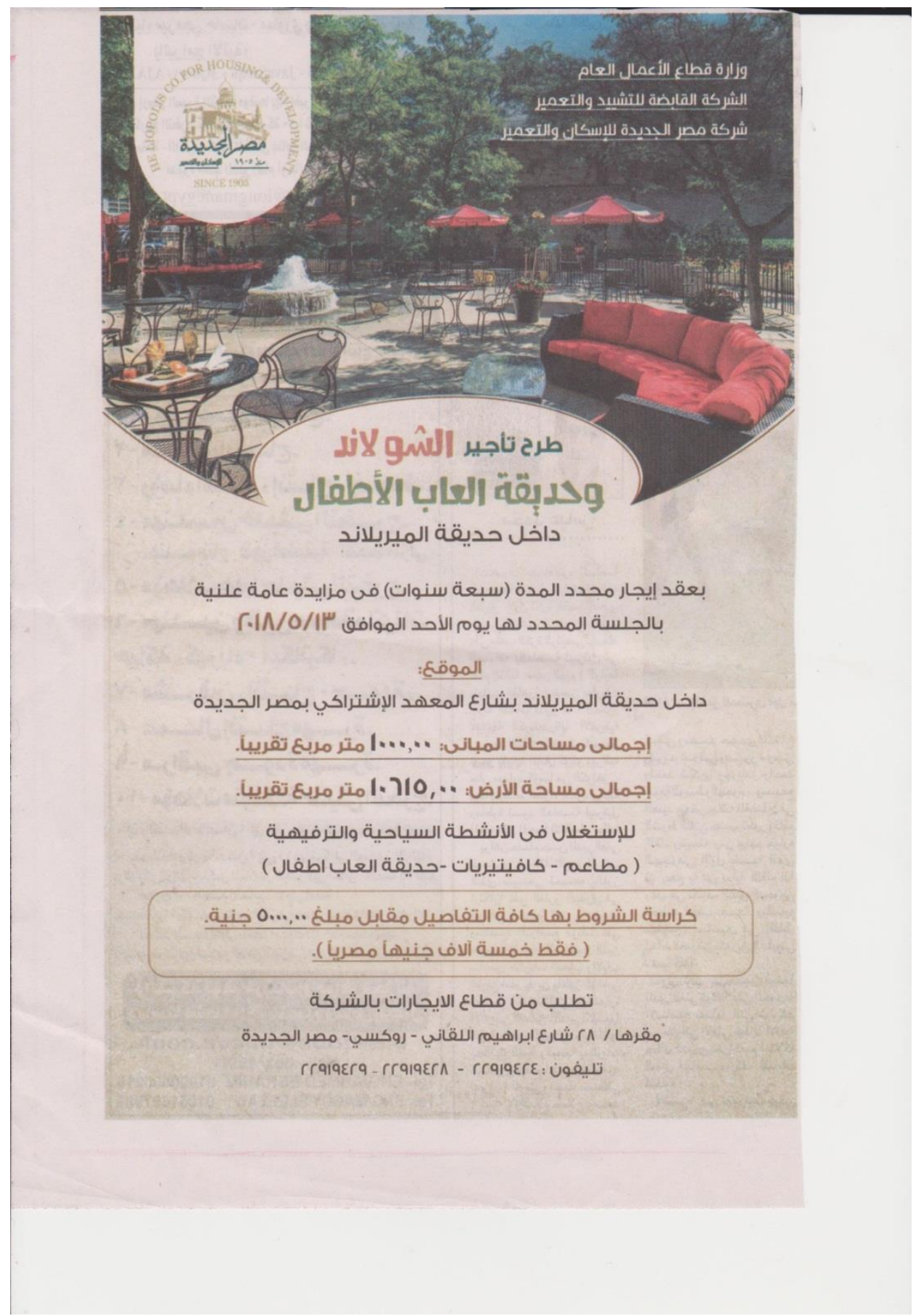


Ad (4)

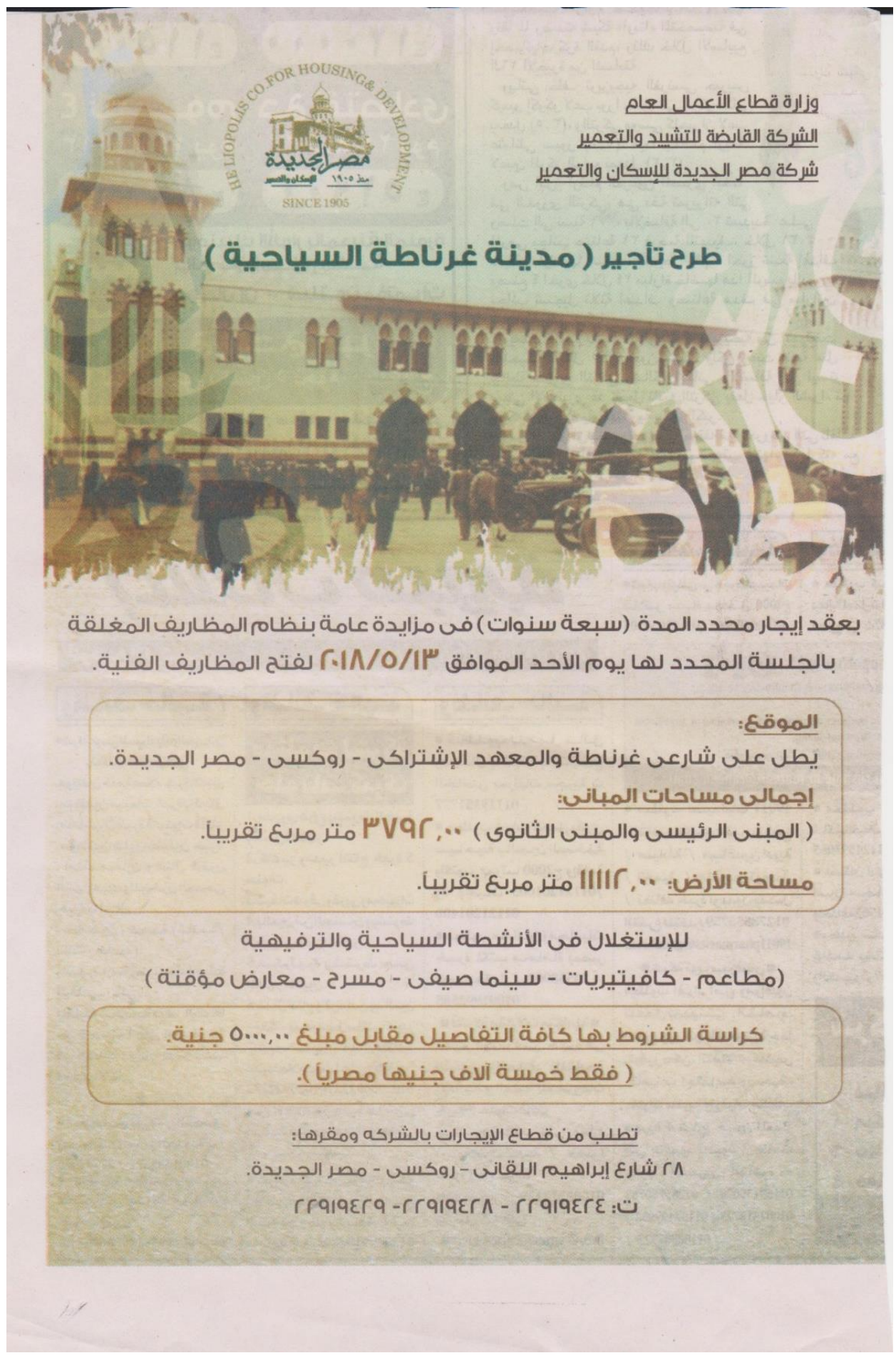


Ad (5)

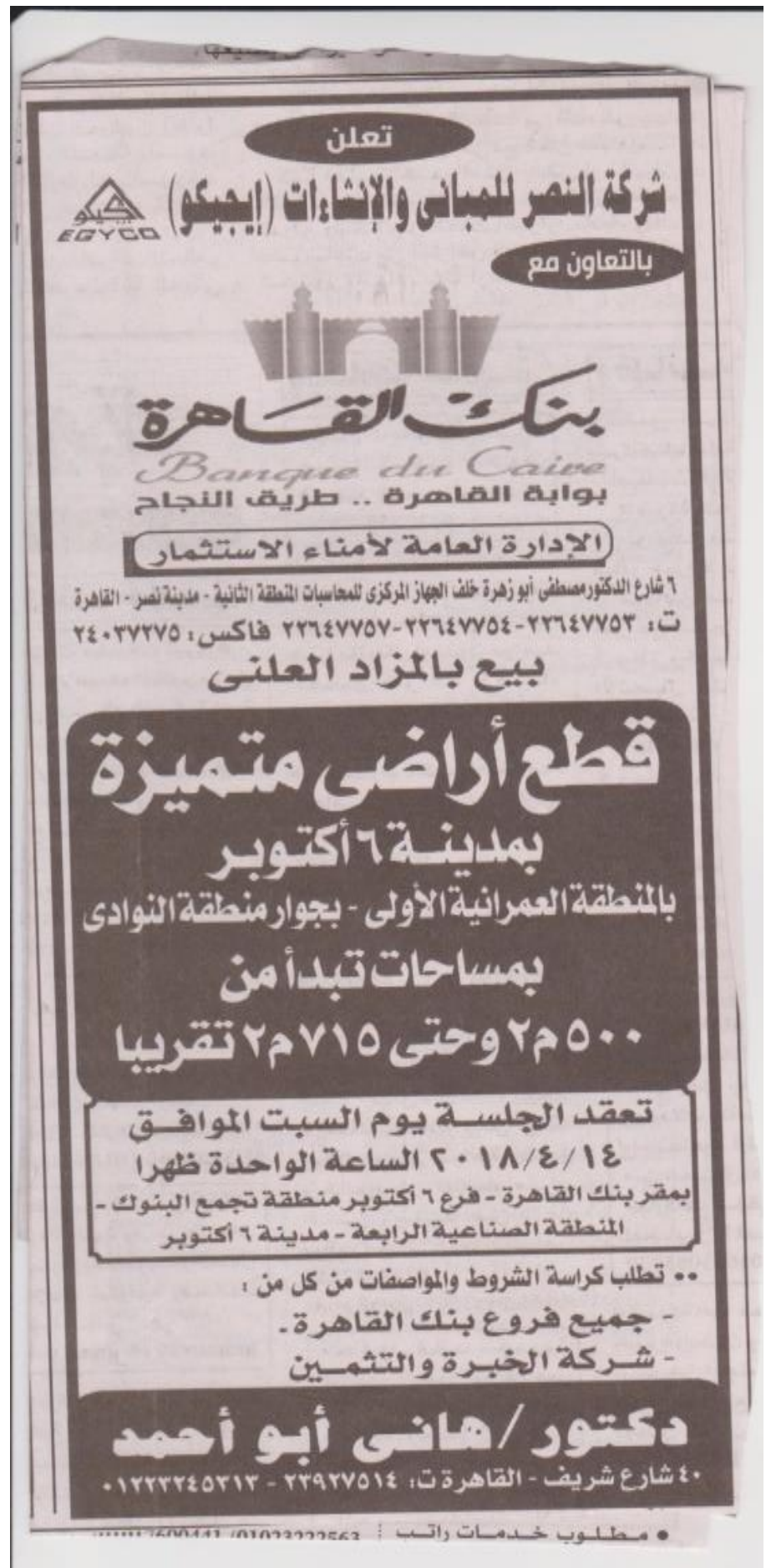


Ad 6

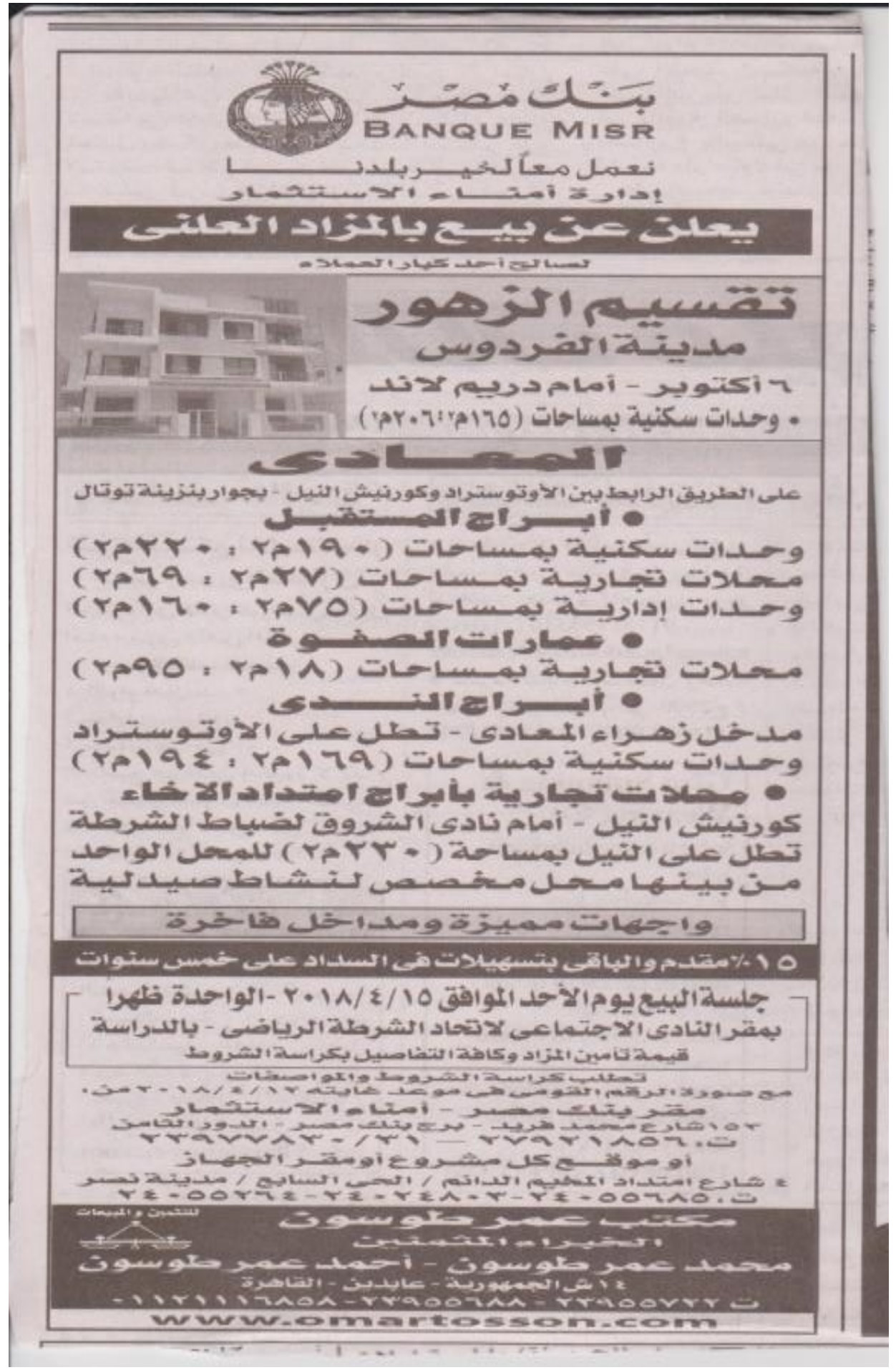


Ad 7

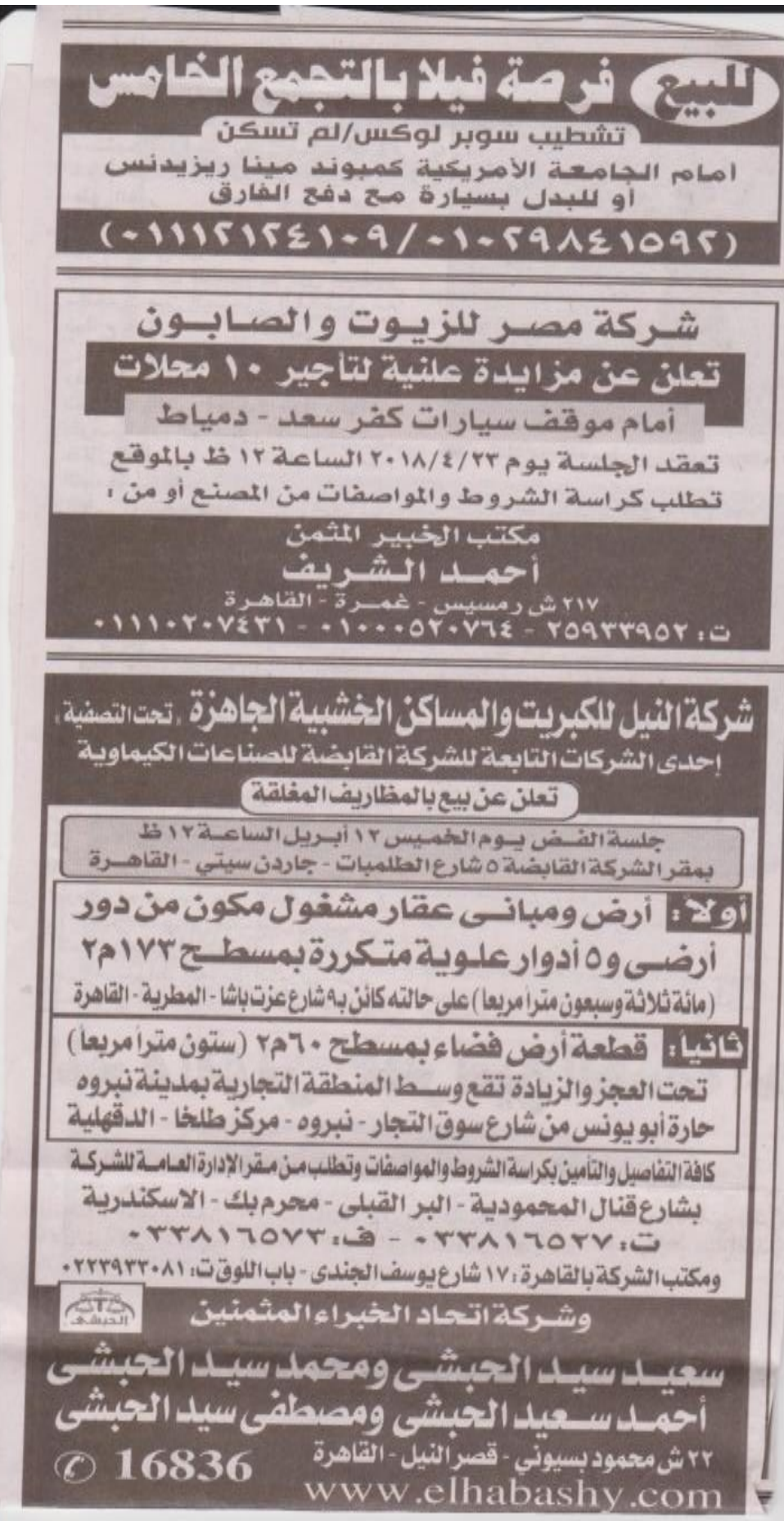


Ad 8

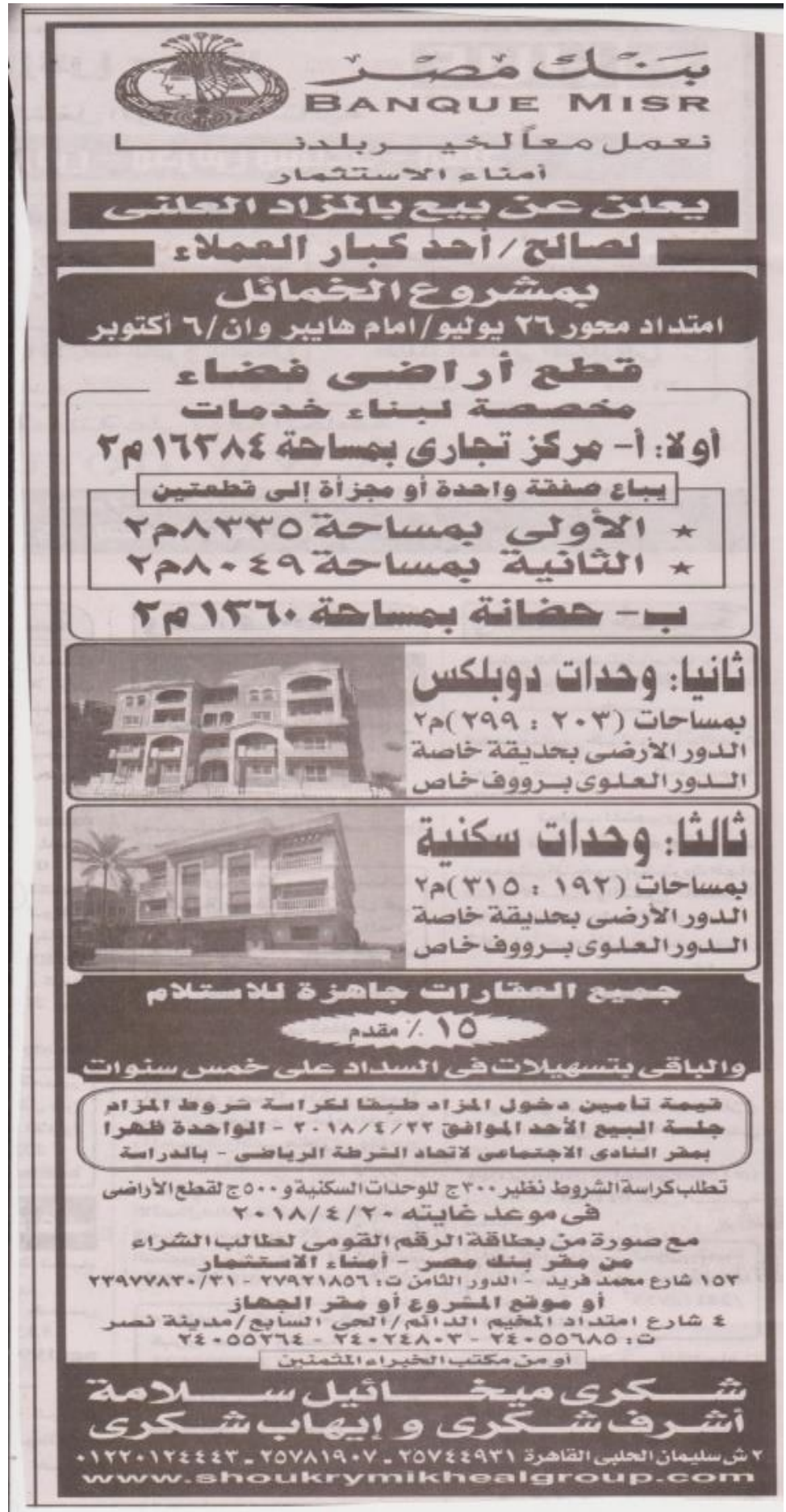


Ad 9

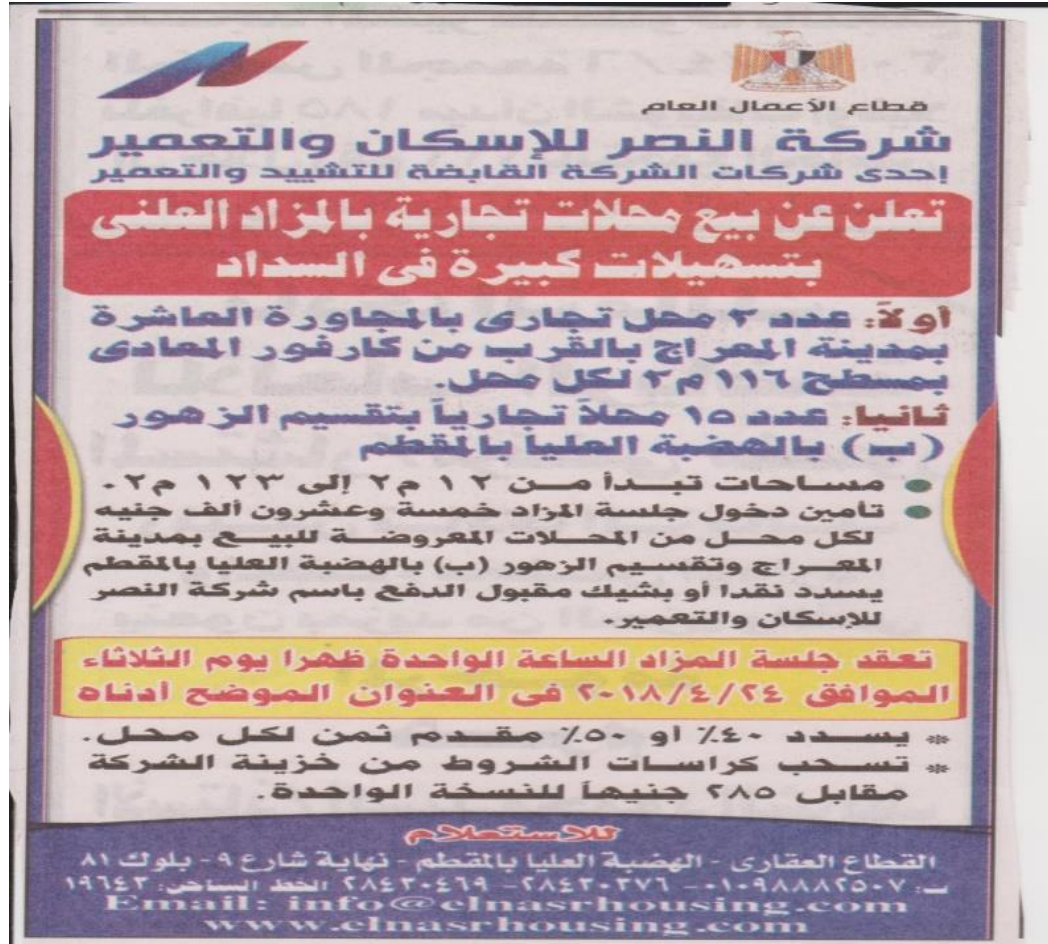

Ad 10

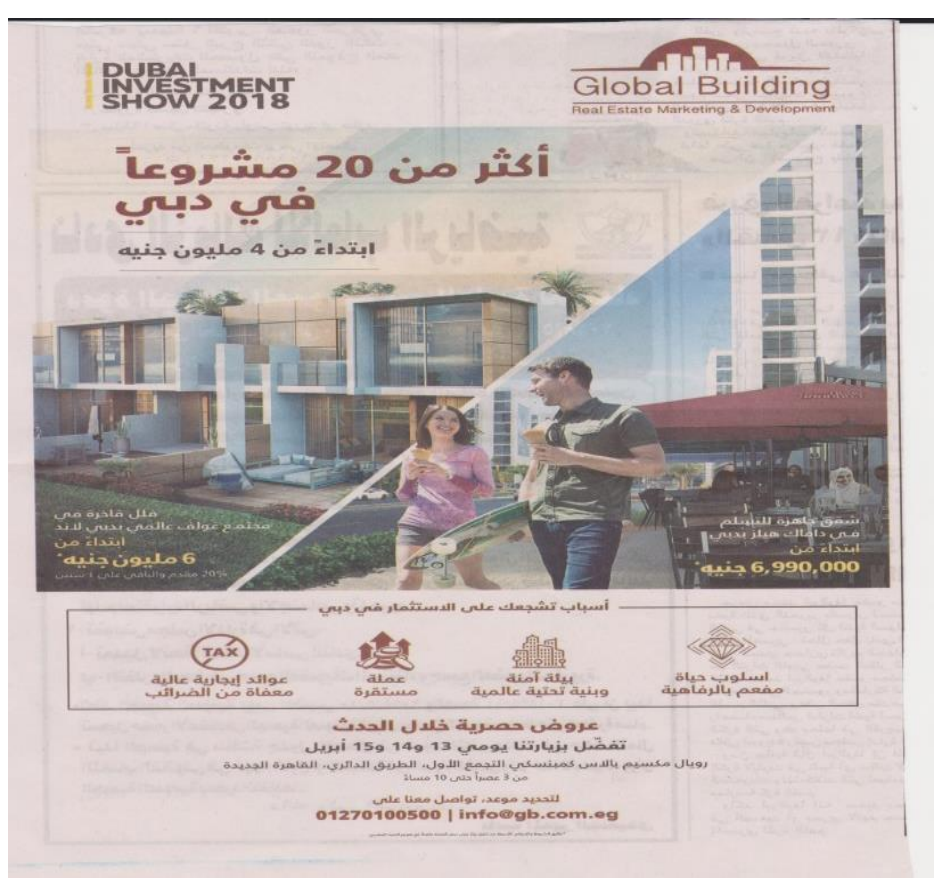


Ad 11

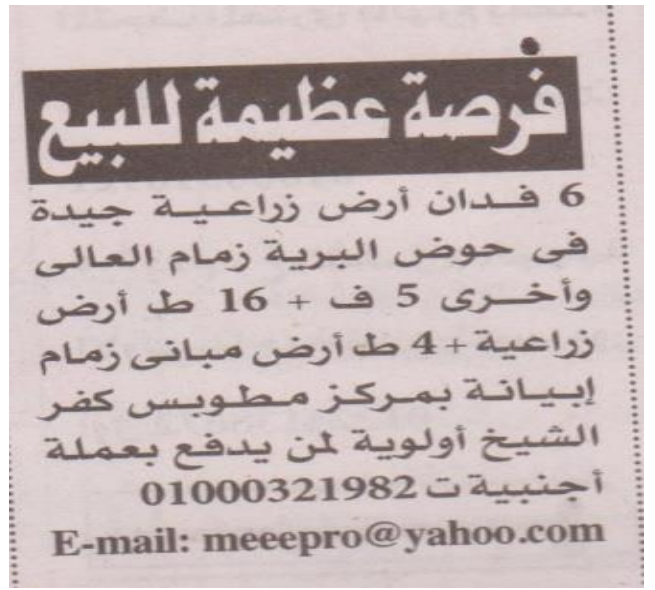

Ad 12

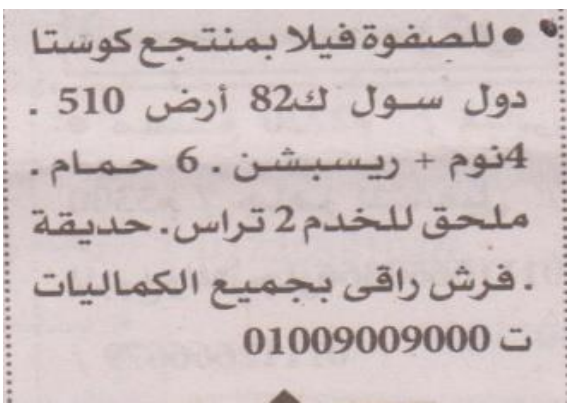

Ad 13

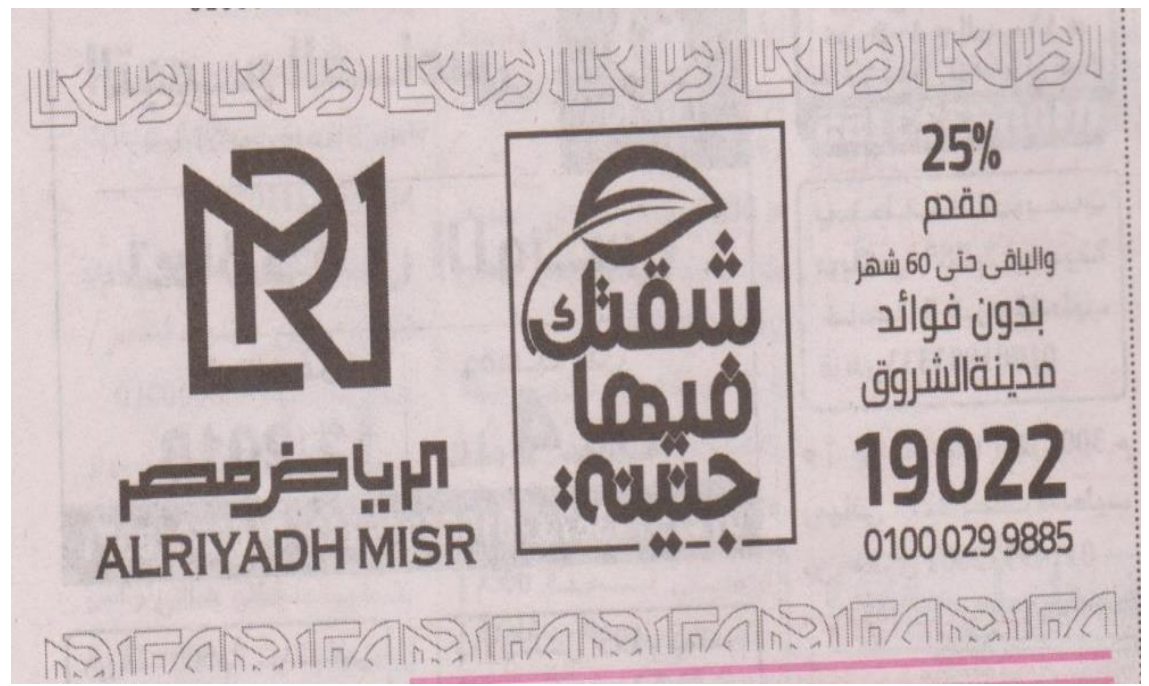


Ad 14

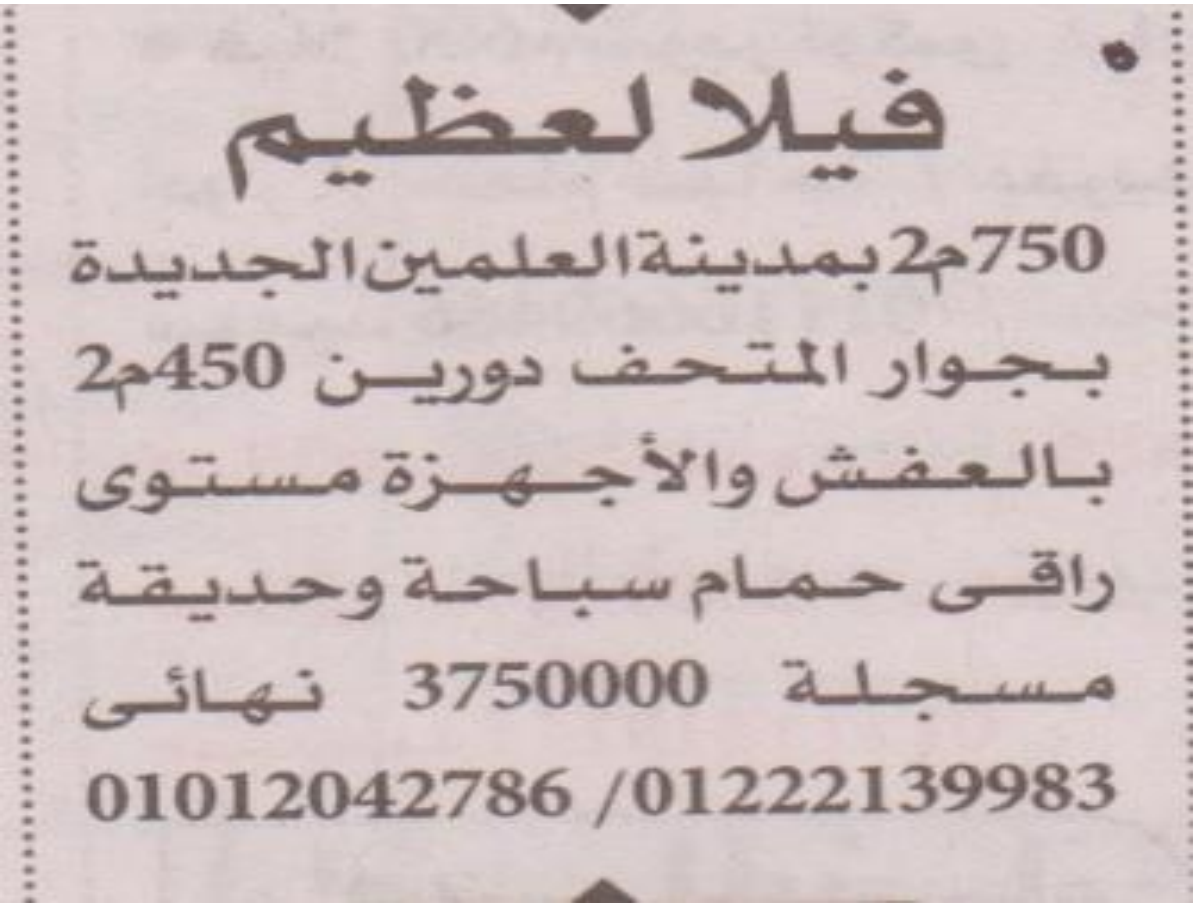

Ad 15

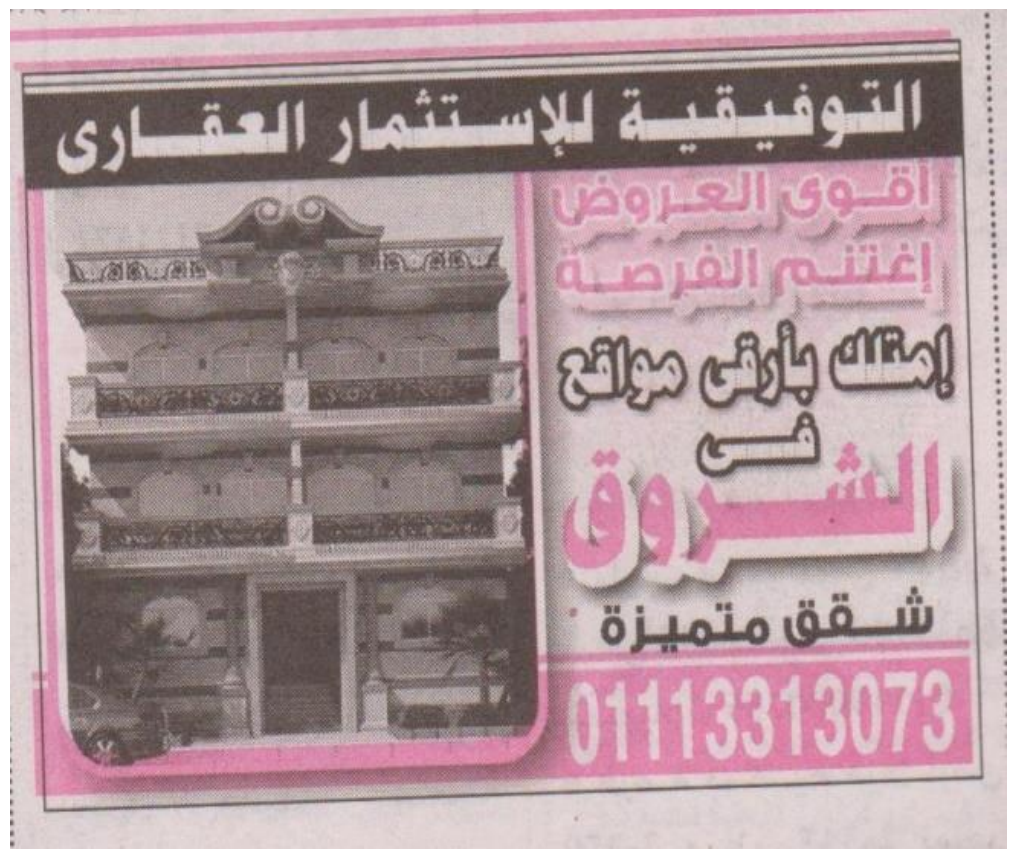


Appendix (B): Week two (13 ${ }^{\text {th }}$ of April 2018)

\section{Al Waseet"The Medium"}

\section{Ad 16}

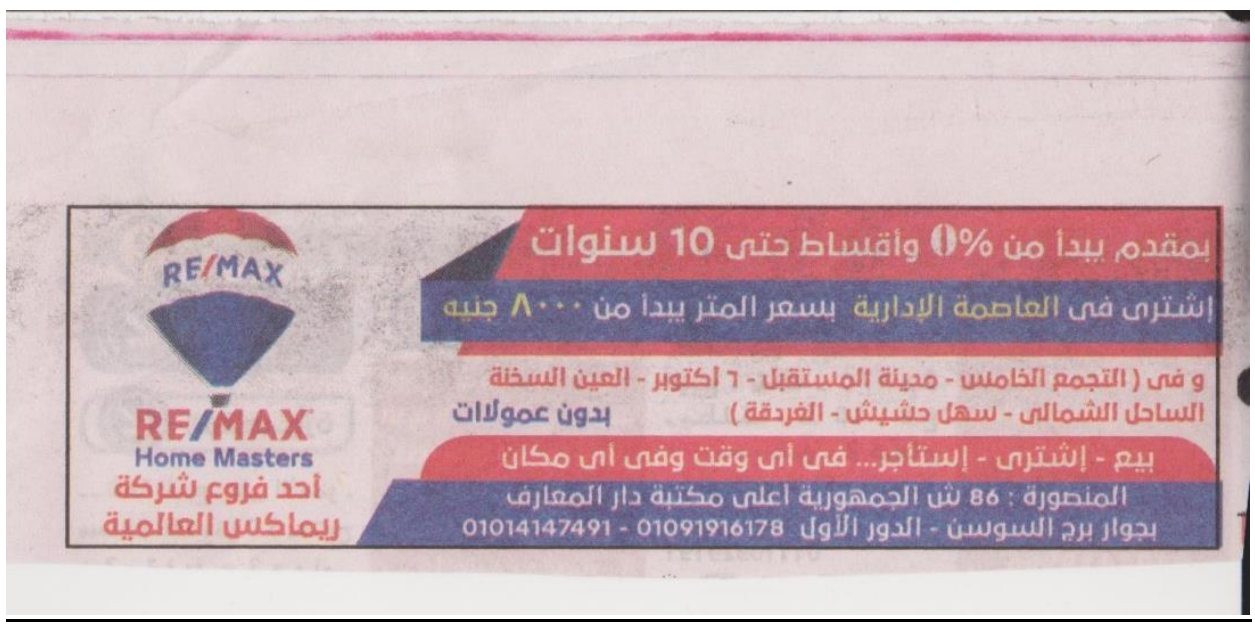

Al-Ahram "The Pyramids"

\section{Ad 17}

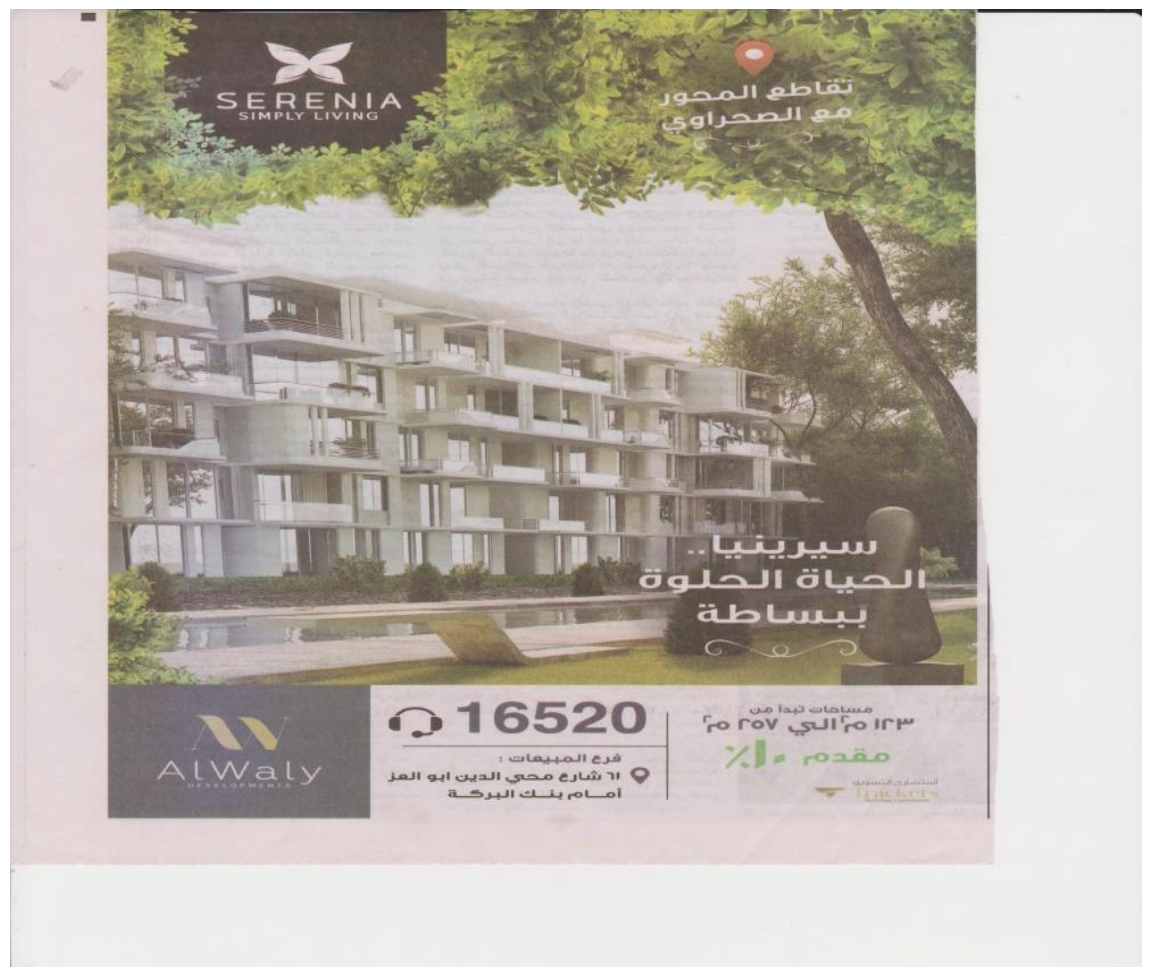


Ad 18

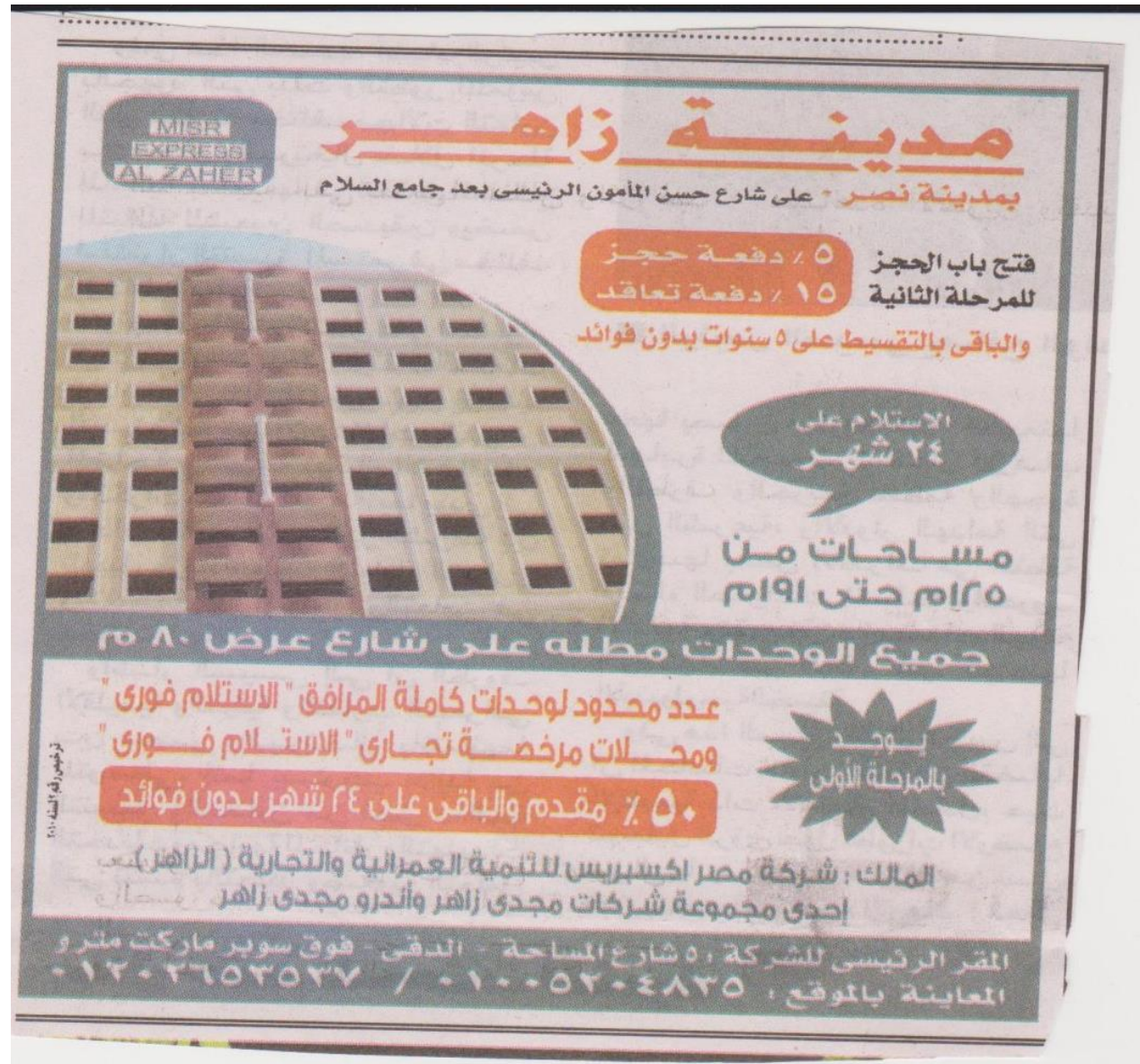

\section{Ad 19}

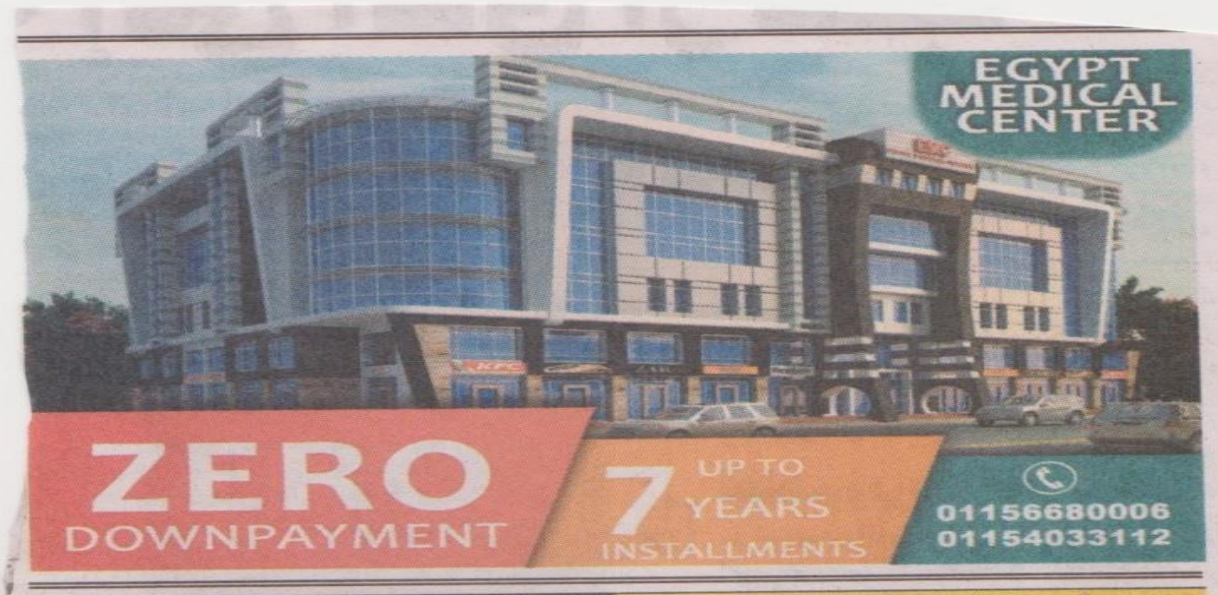


Ad 20

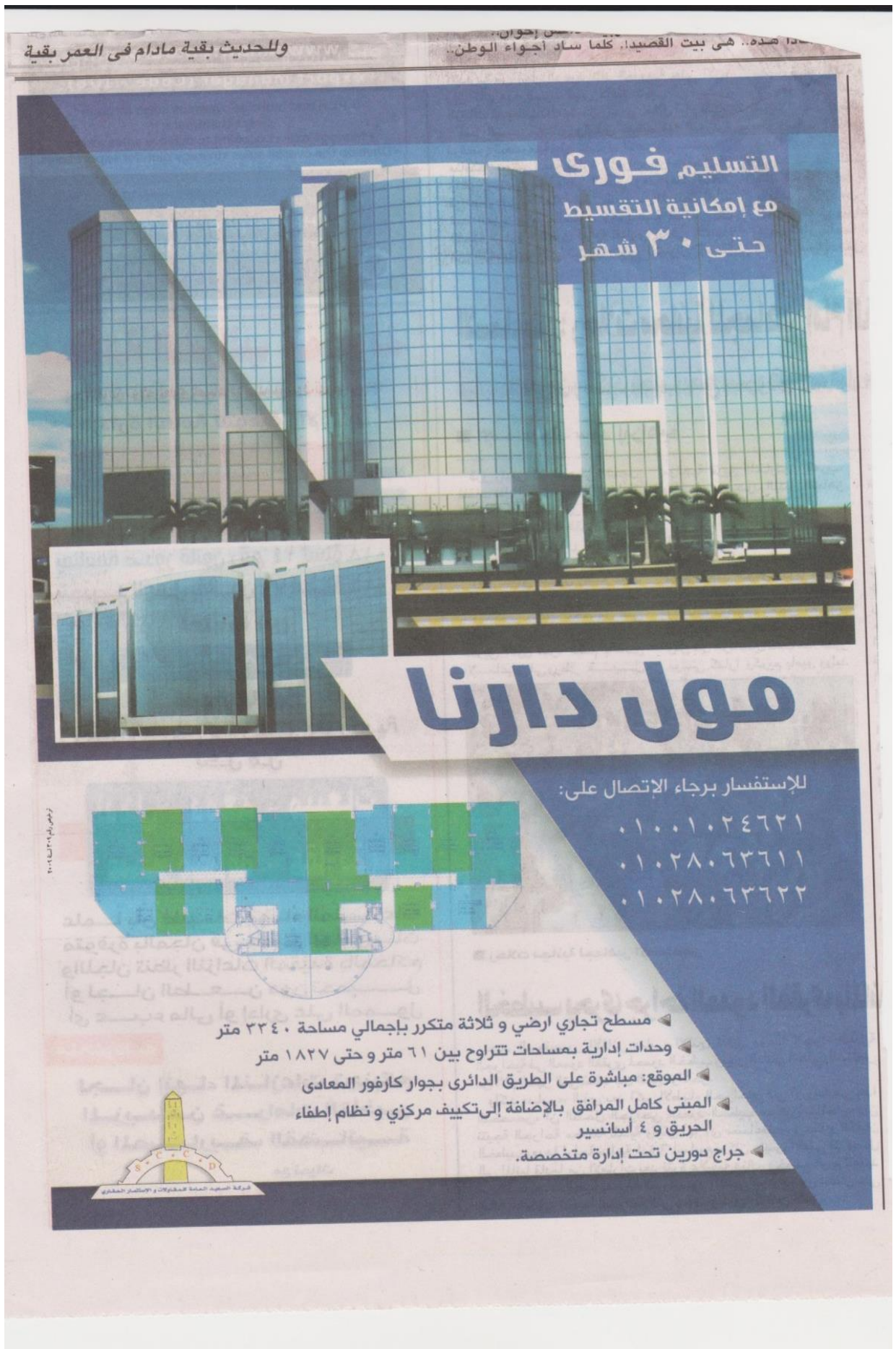




\section{Ad 21}

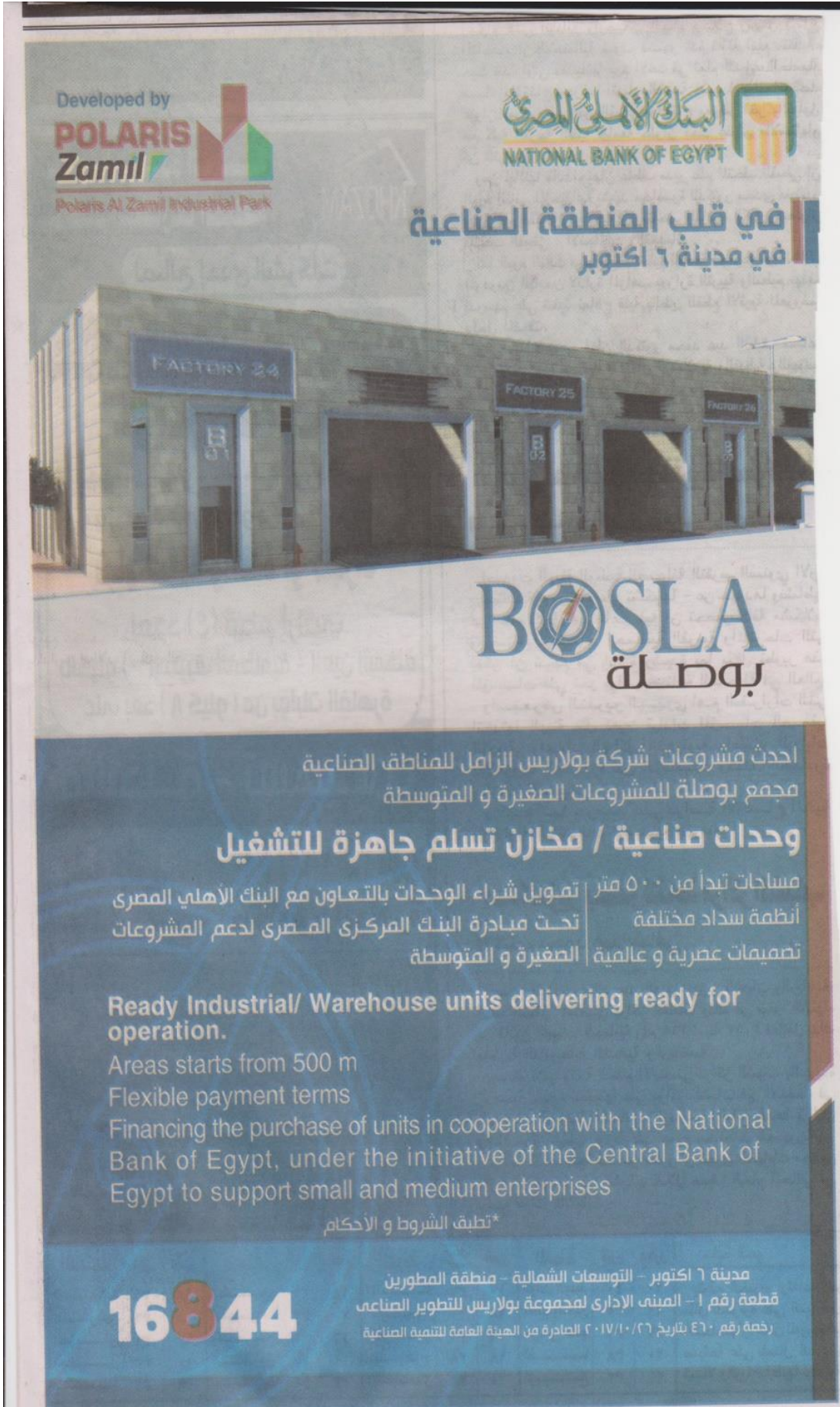


Appendix (C): Week three (20 $0^{\text {th }}$ of April 2018)

\section{Al Waseet"The Medium"}

\section{Ad 22}

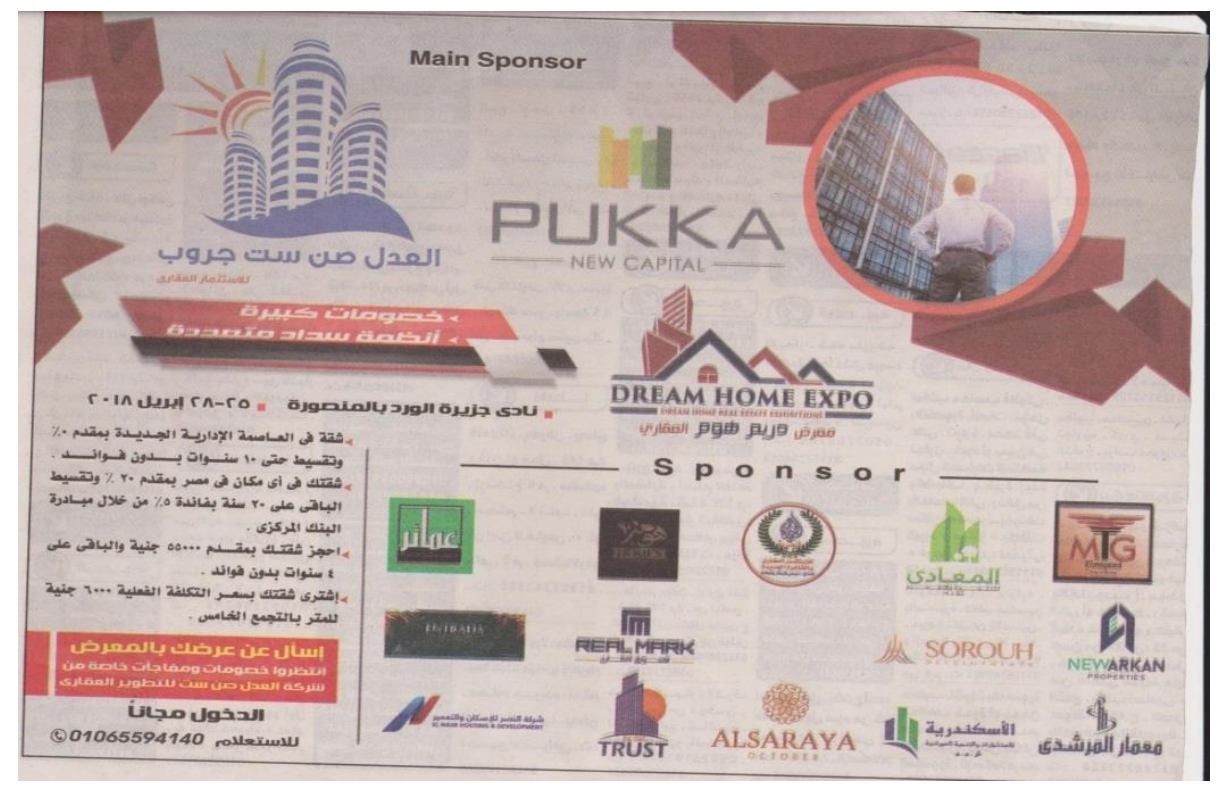

Ad 23

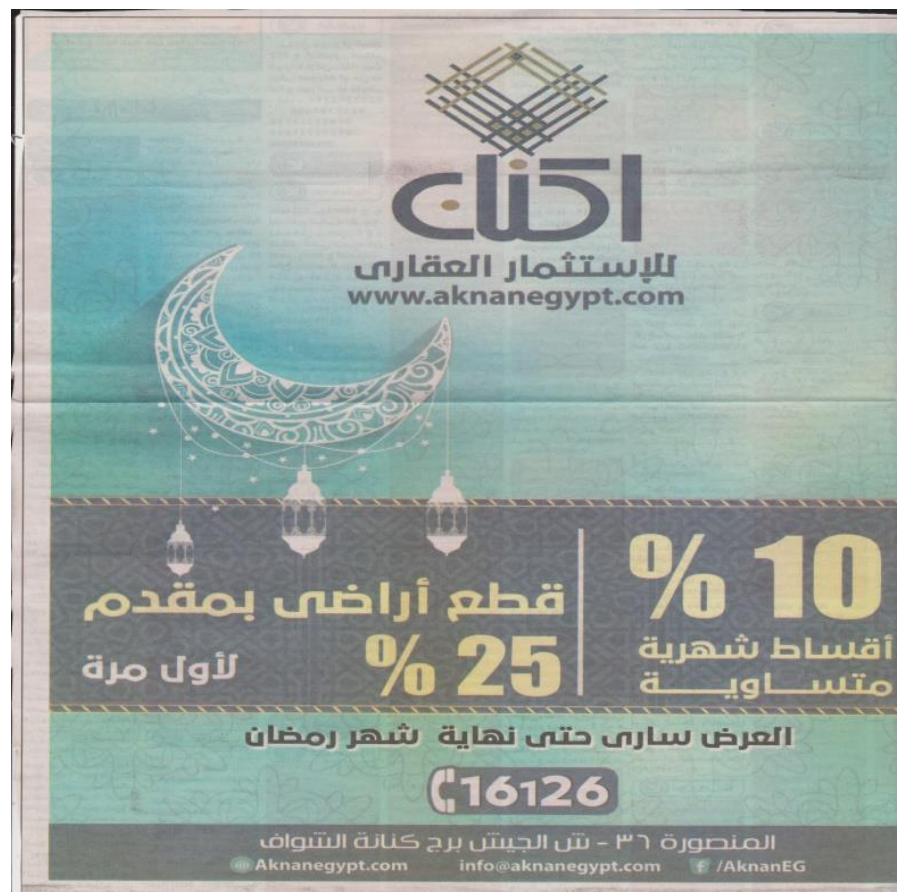


Al-Ahram "The Pyramids"

Ad 24

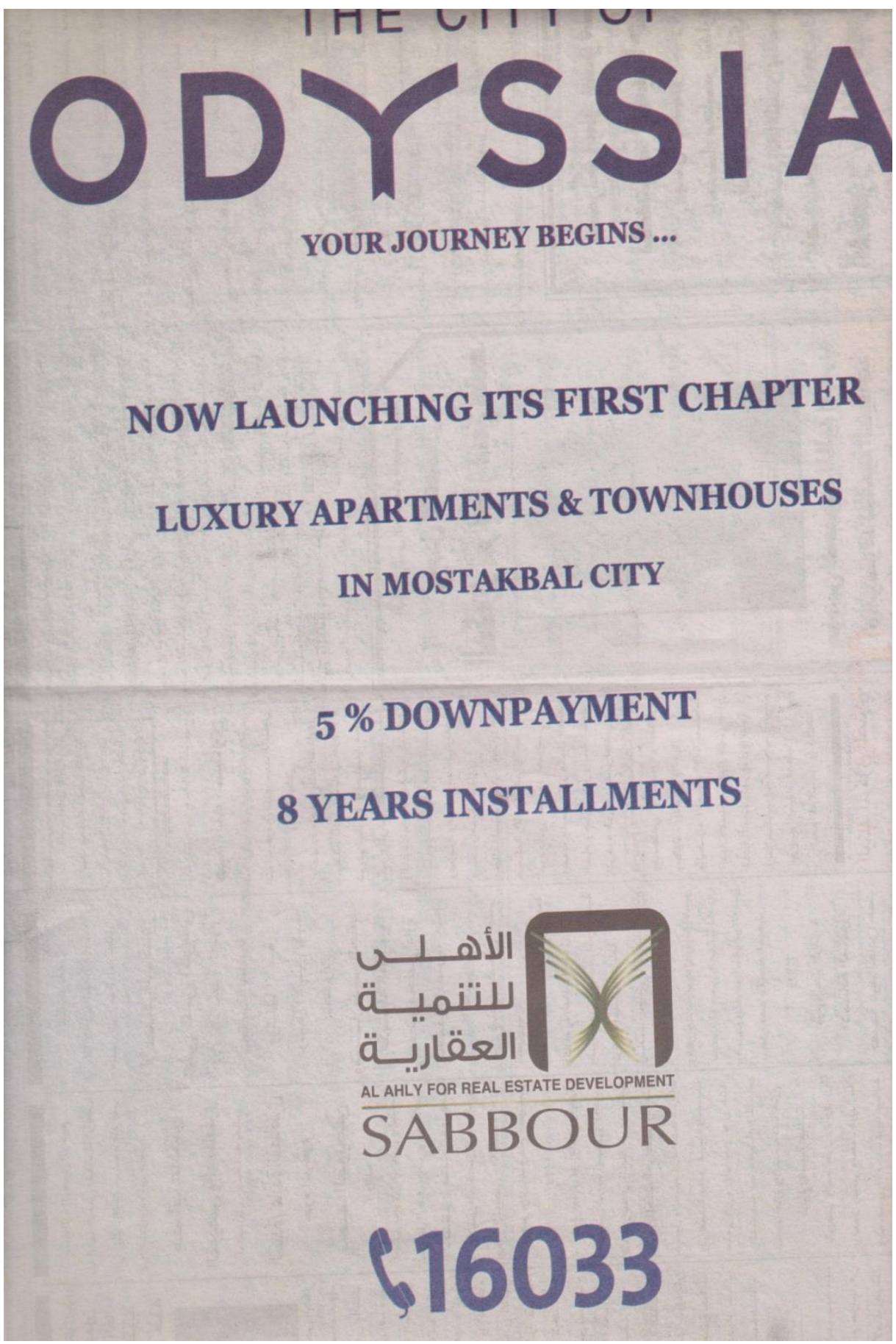


Ad 25

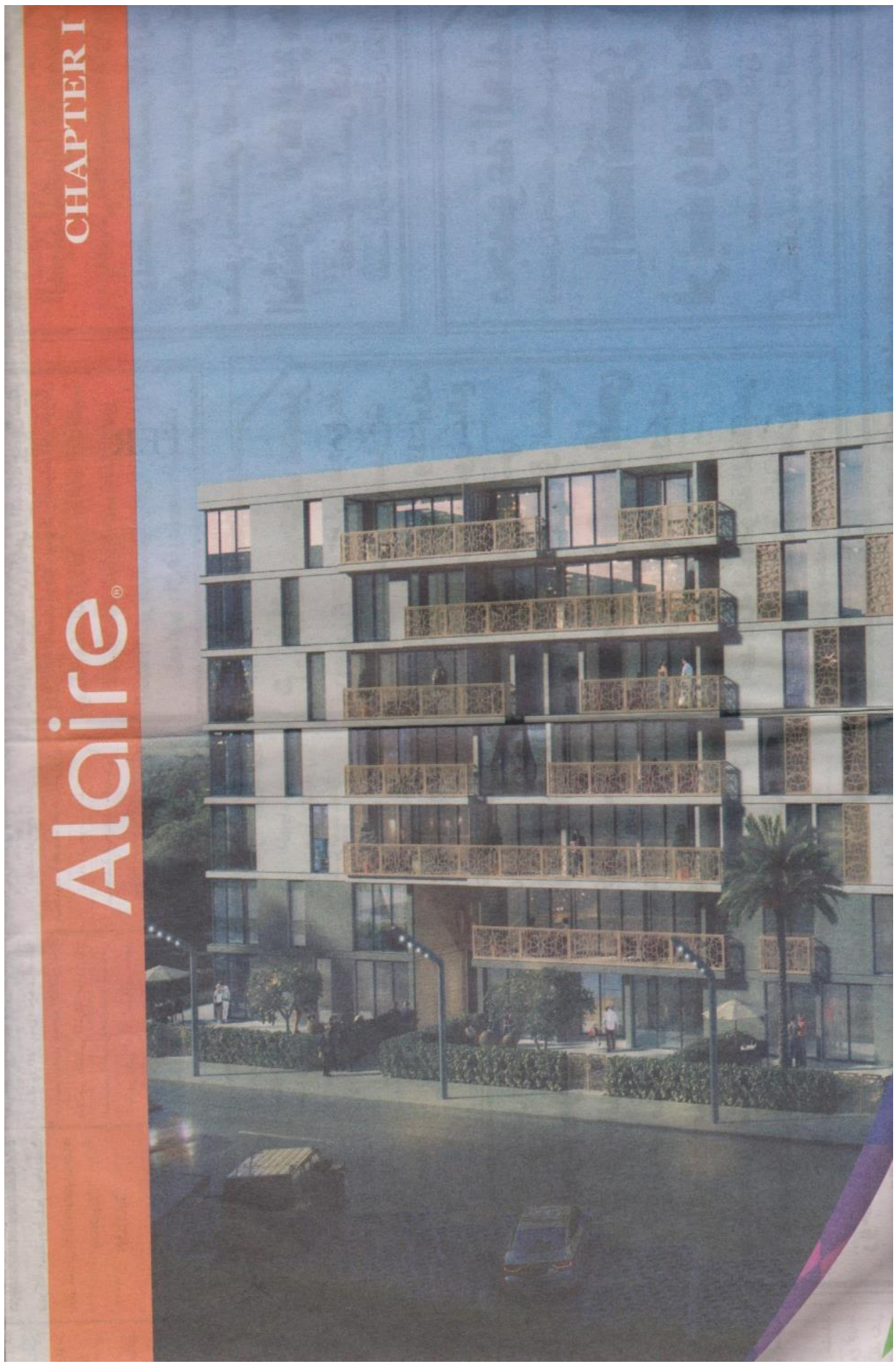


Ad 26

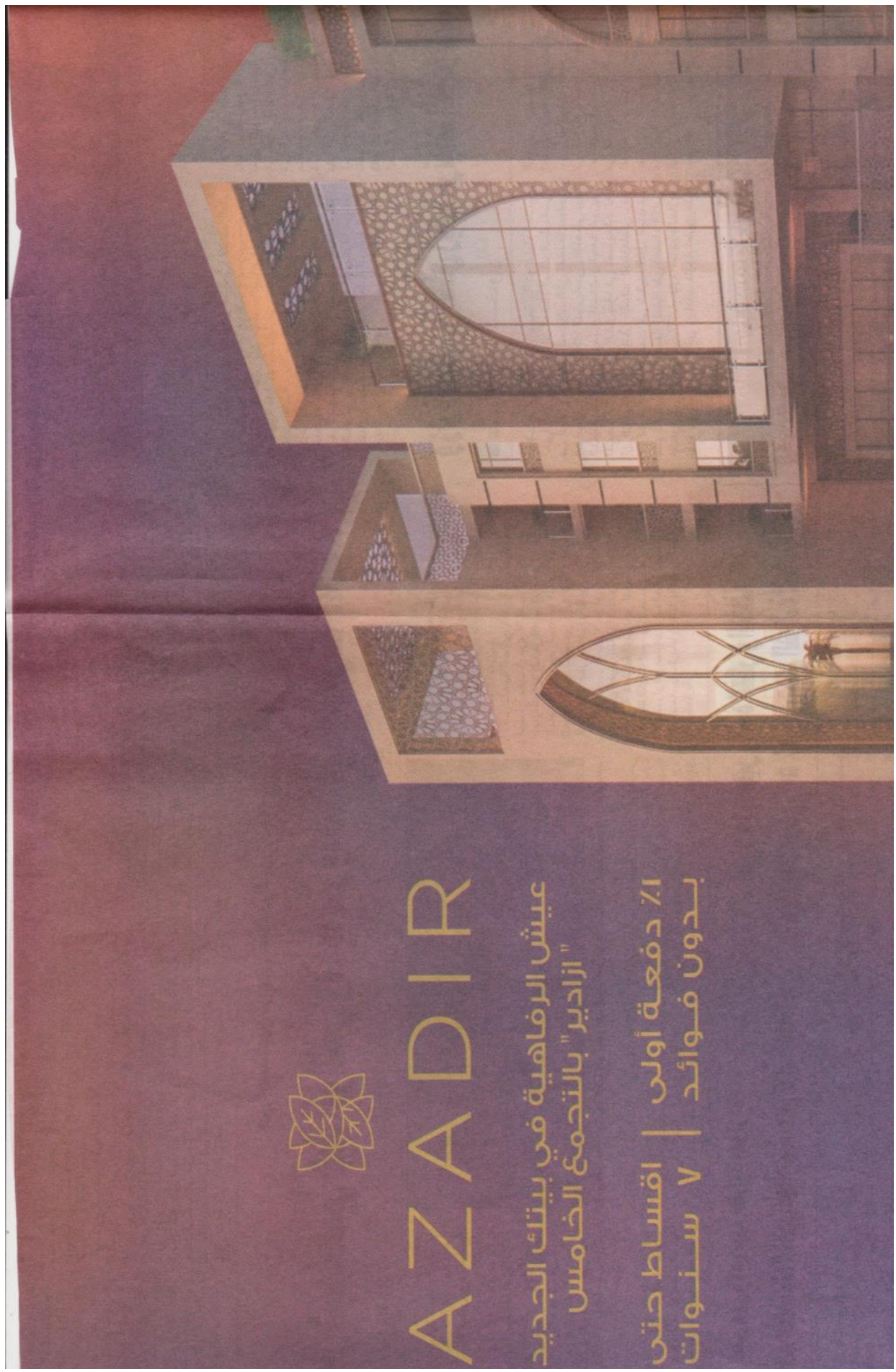


Ad 27

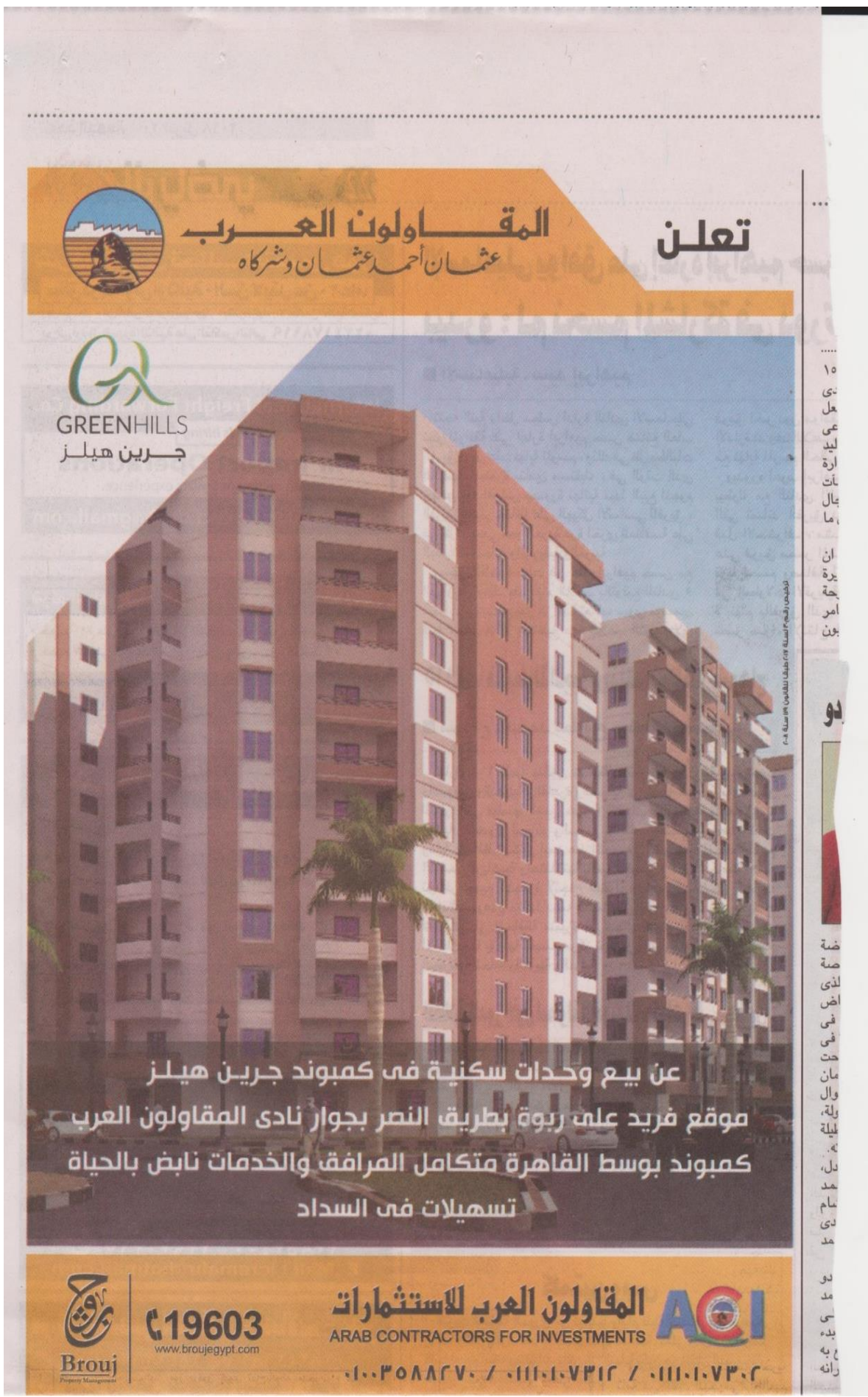


Ad 28

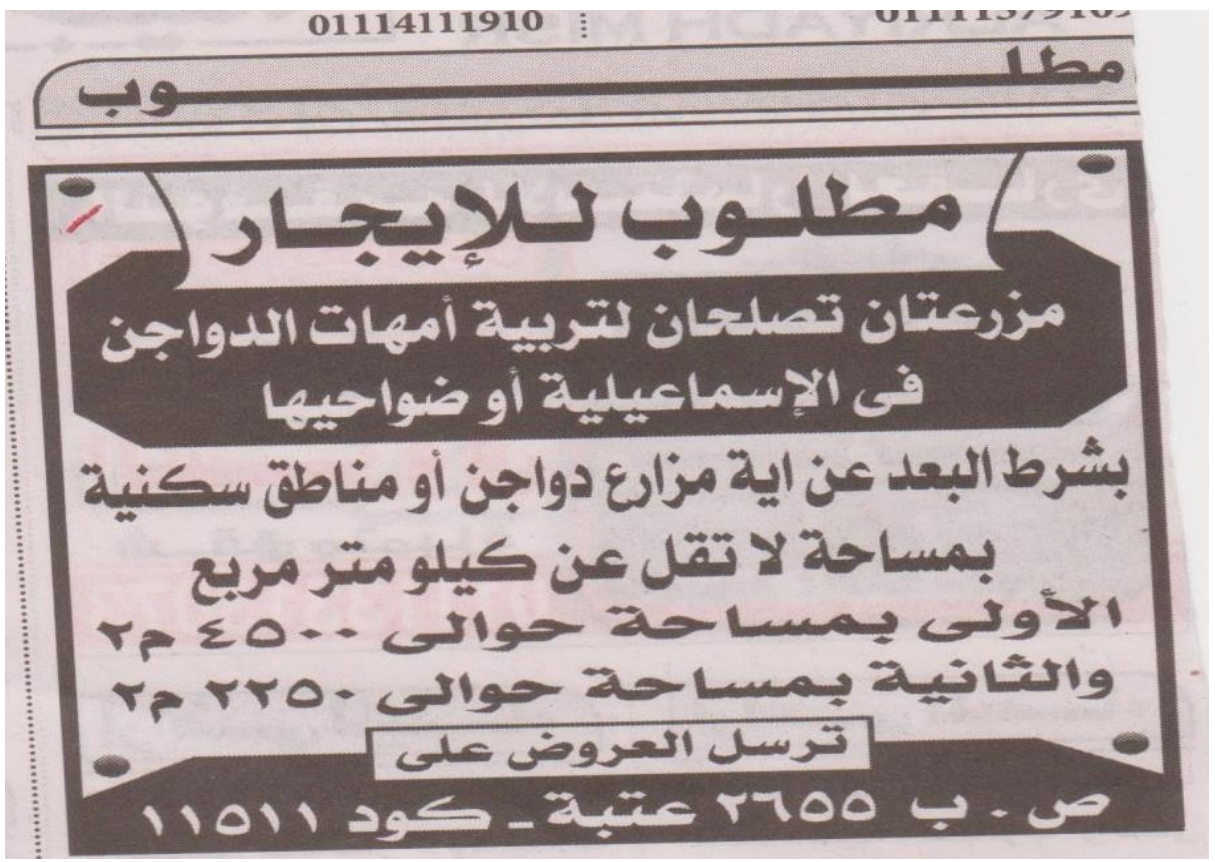

Ad 29

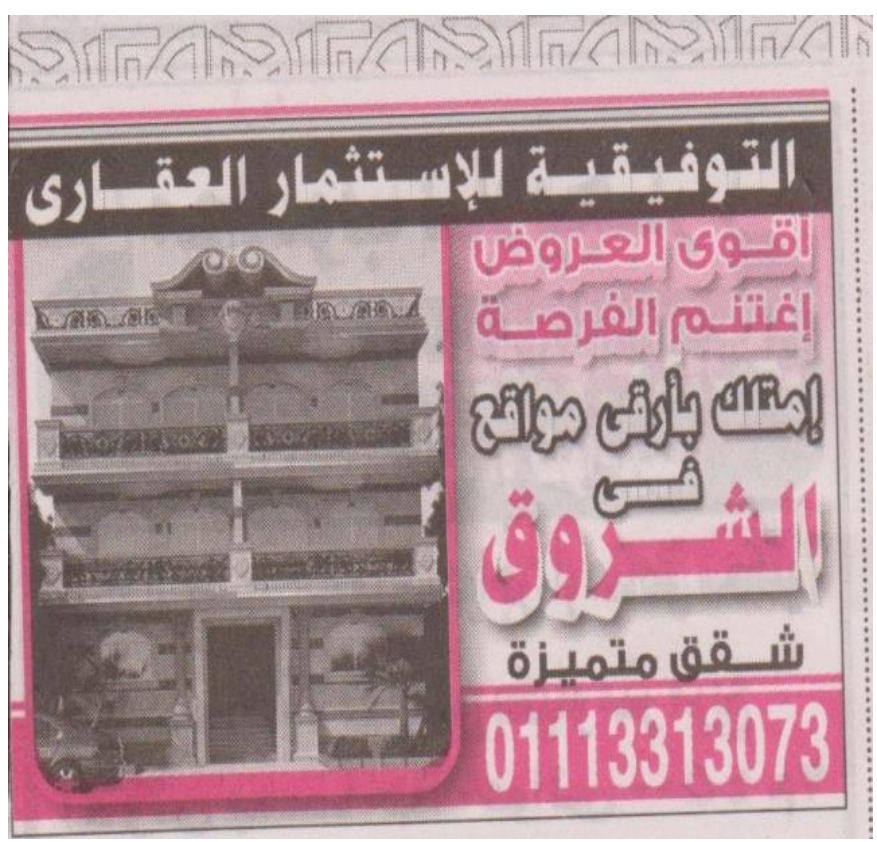


Ad 30

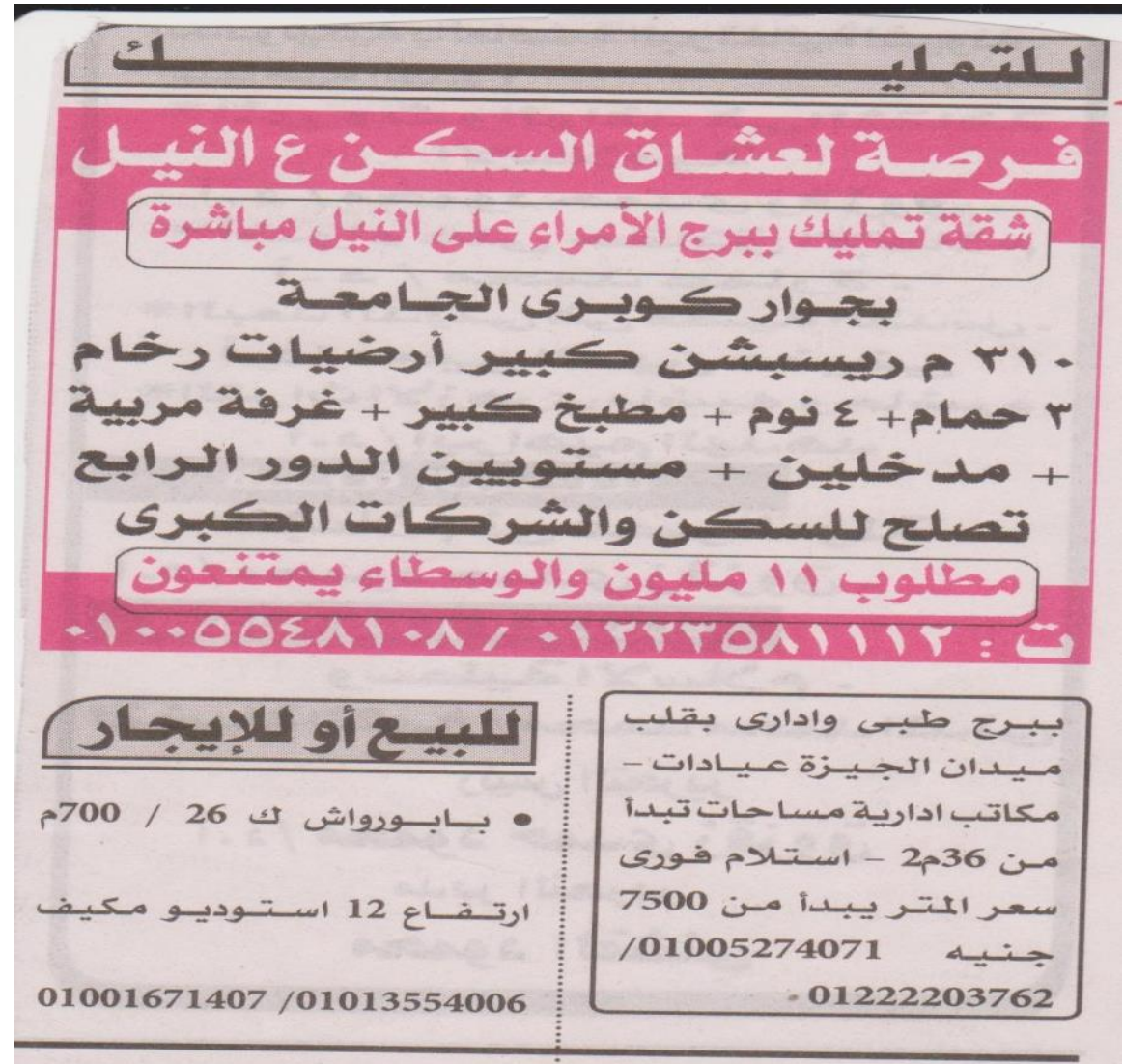

Ad 31

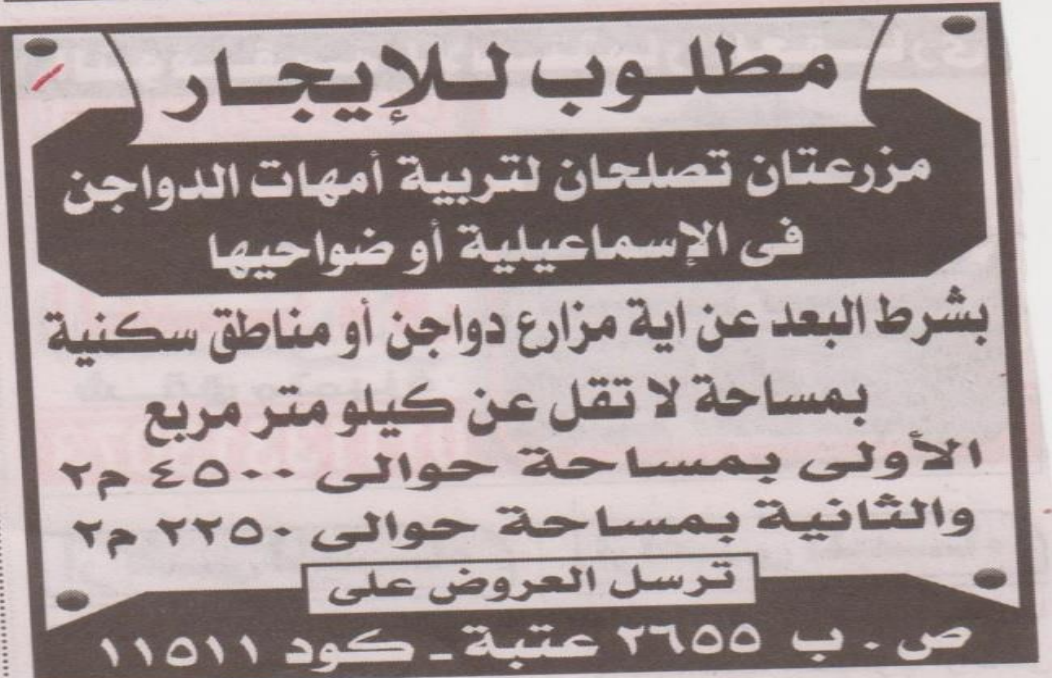


Ad 32

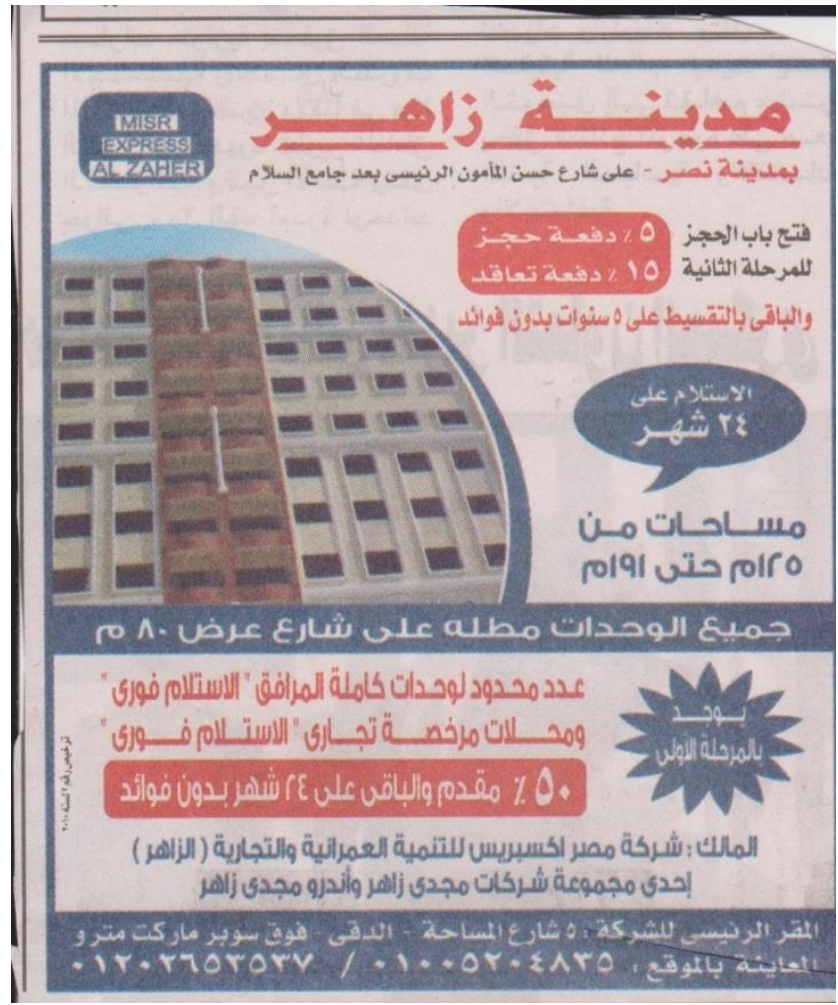

Ad 33

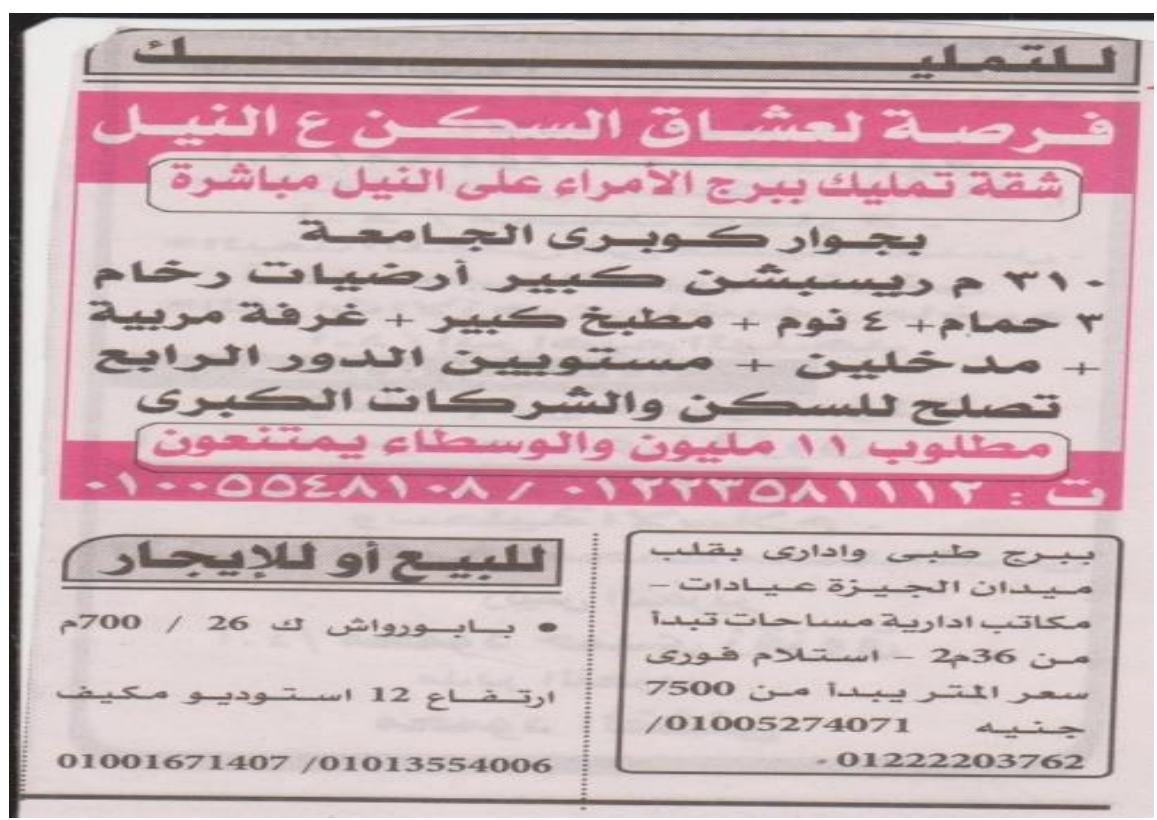


Appendix (D): Week four (27 $7^{\text {th }}$ of April 2018)

\section{Al-Ahram "The Pyramids"}

\section{Ad 34}

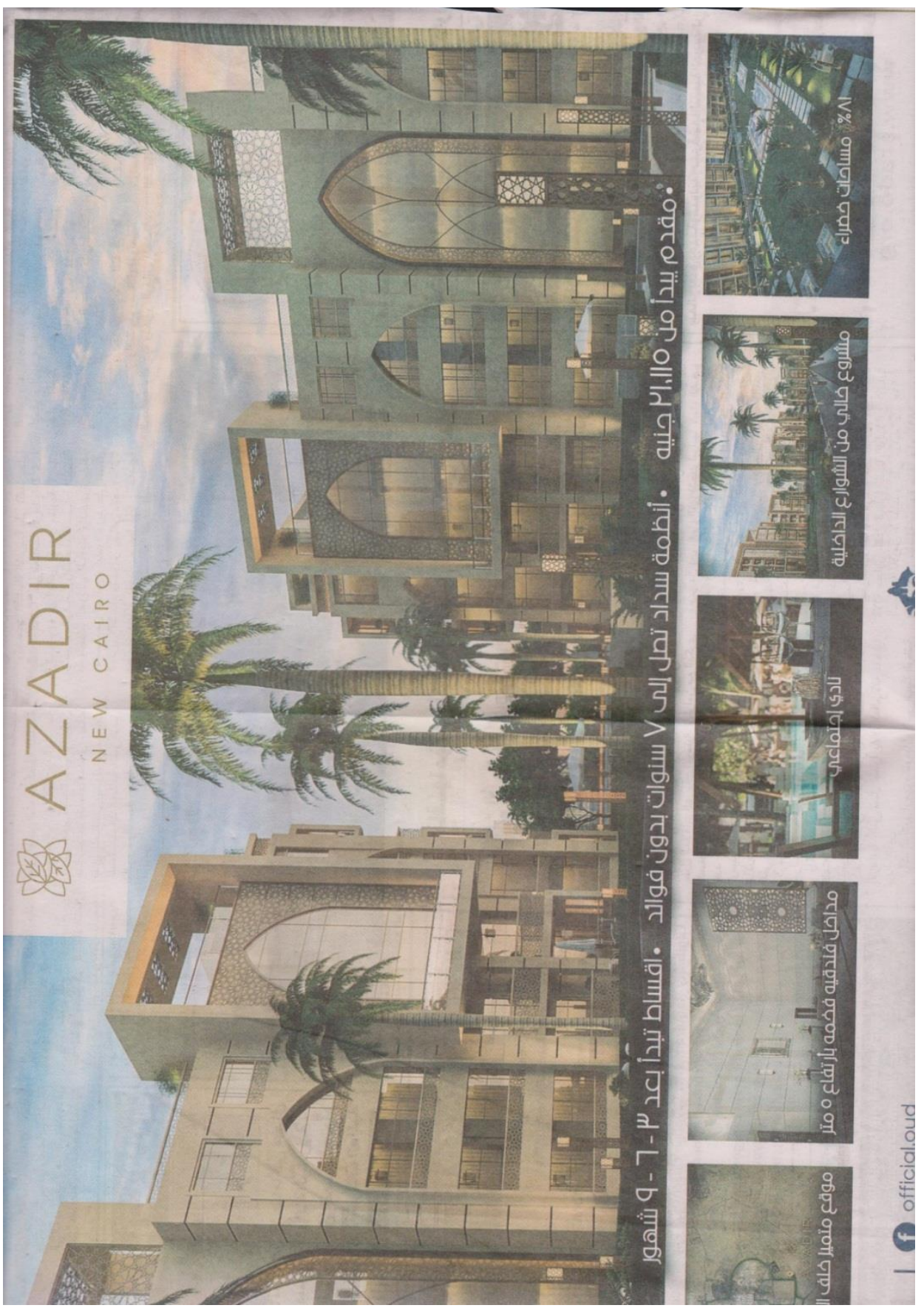


Ad 35

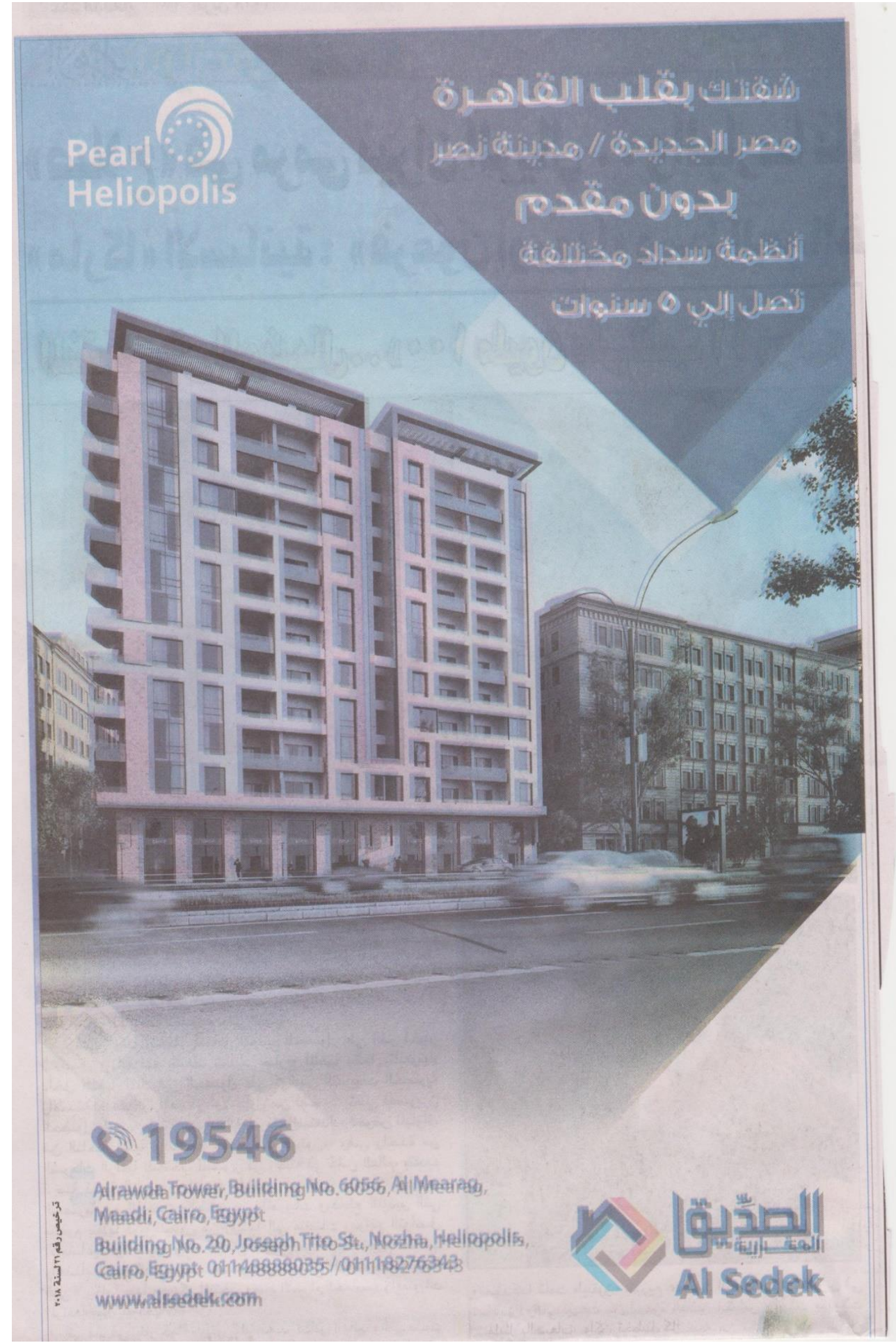


Ad 36

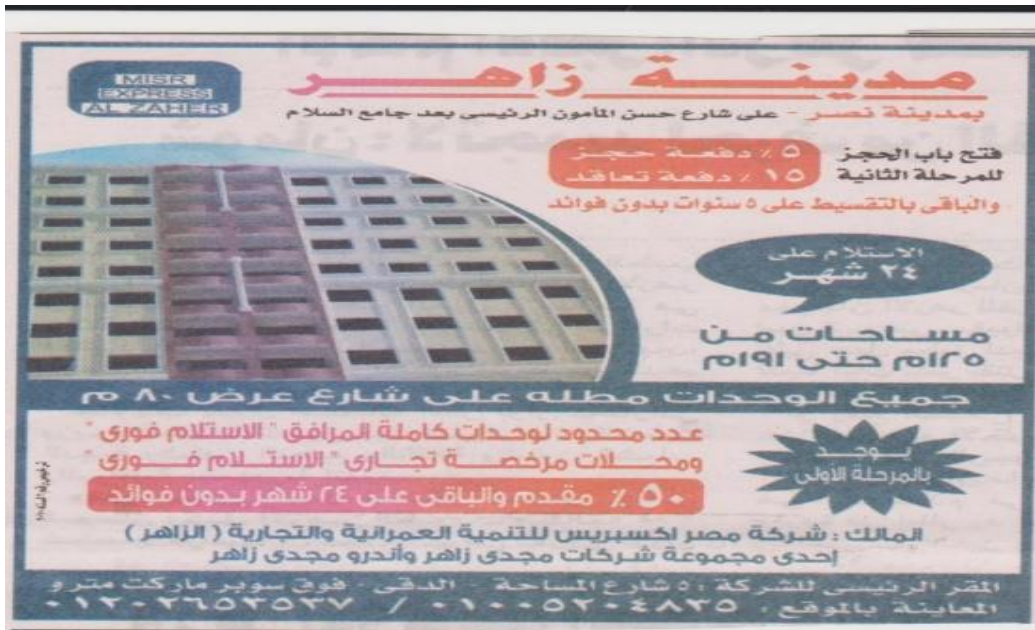

Ad 37

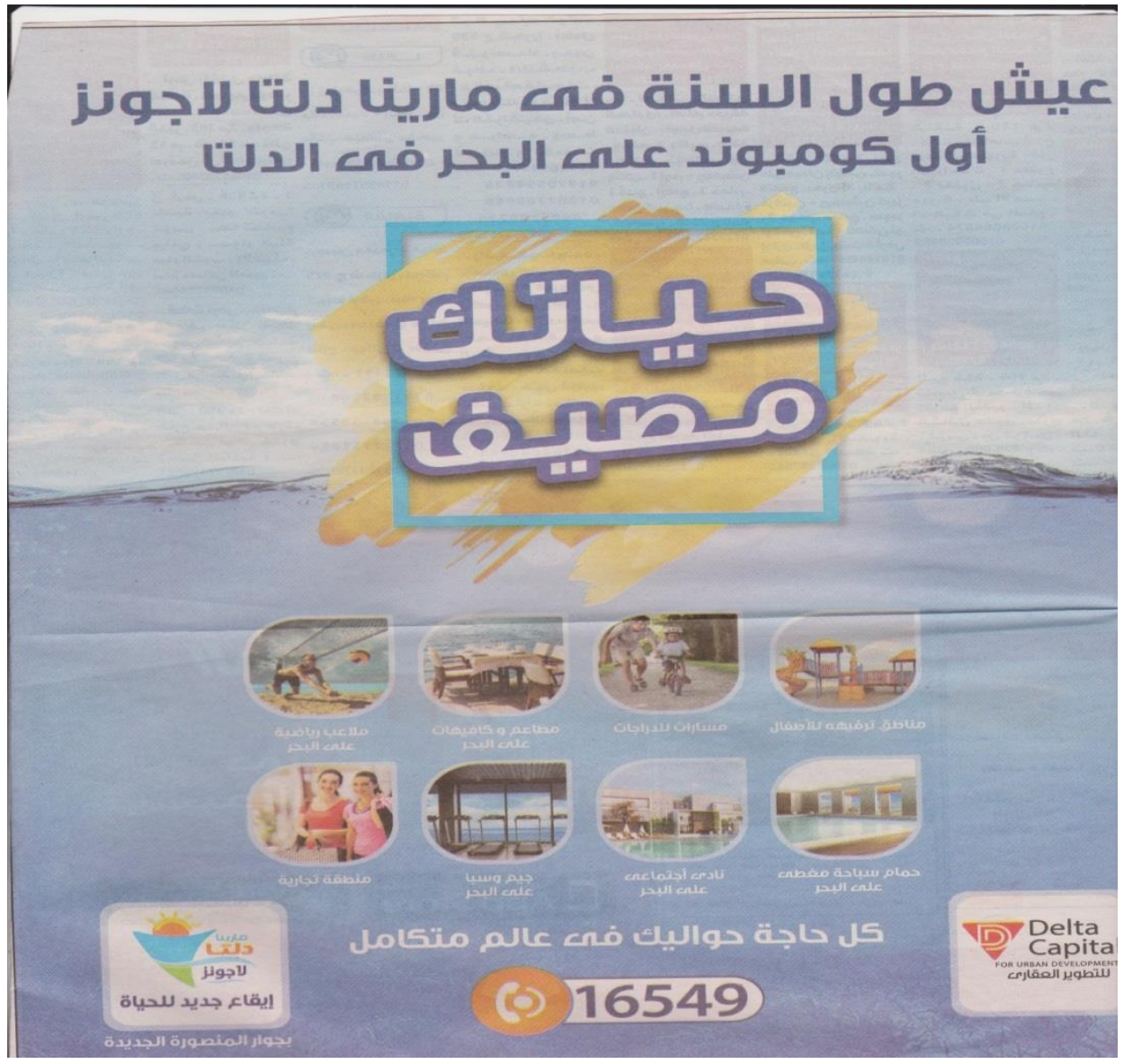


Ad 38

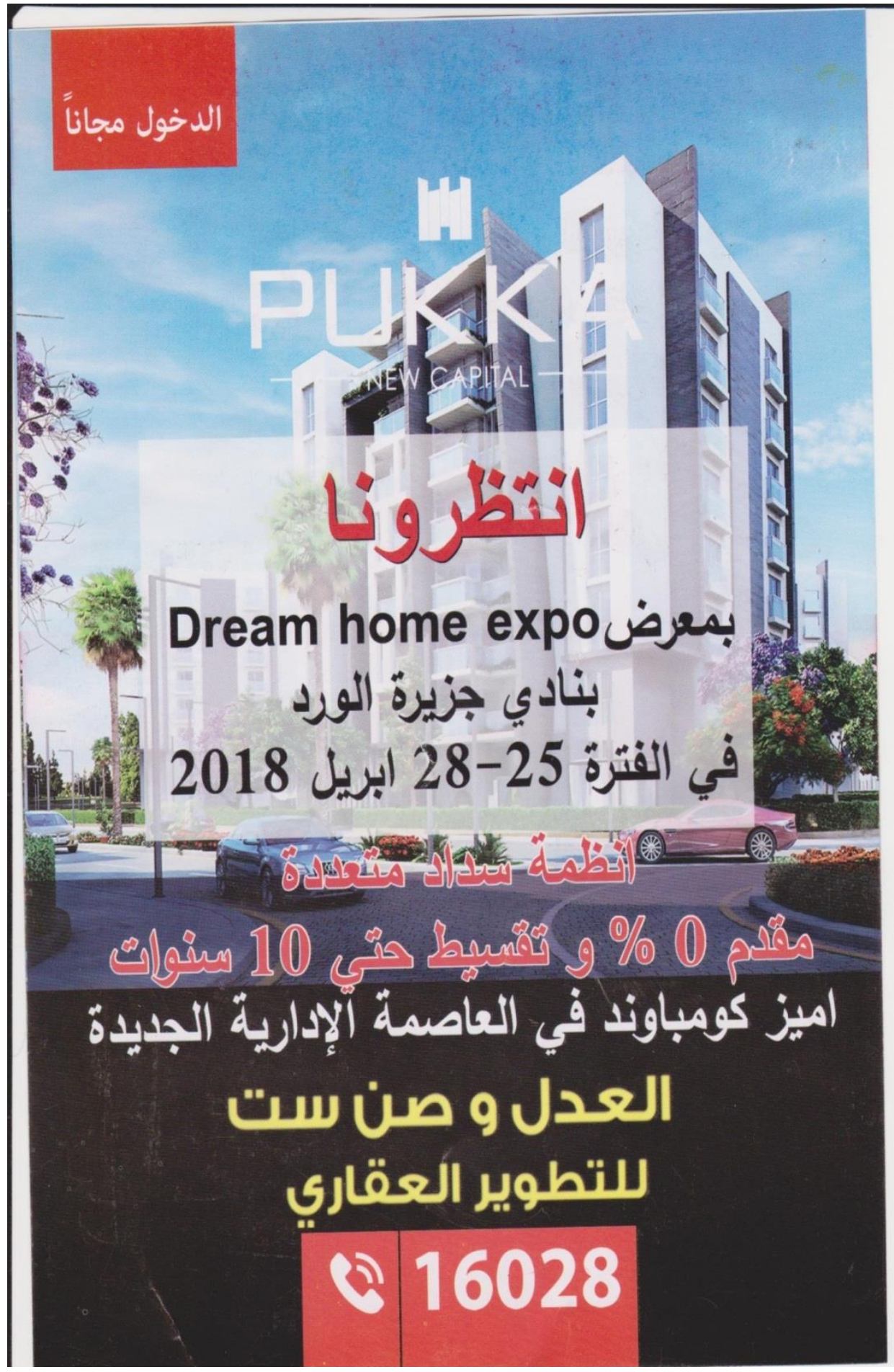


Ad 39

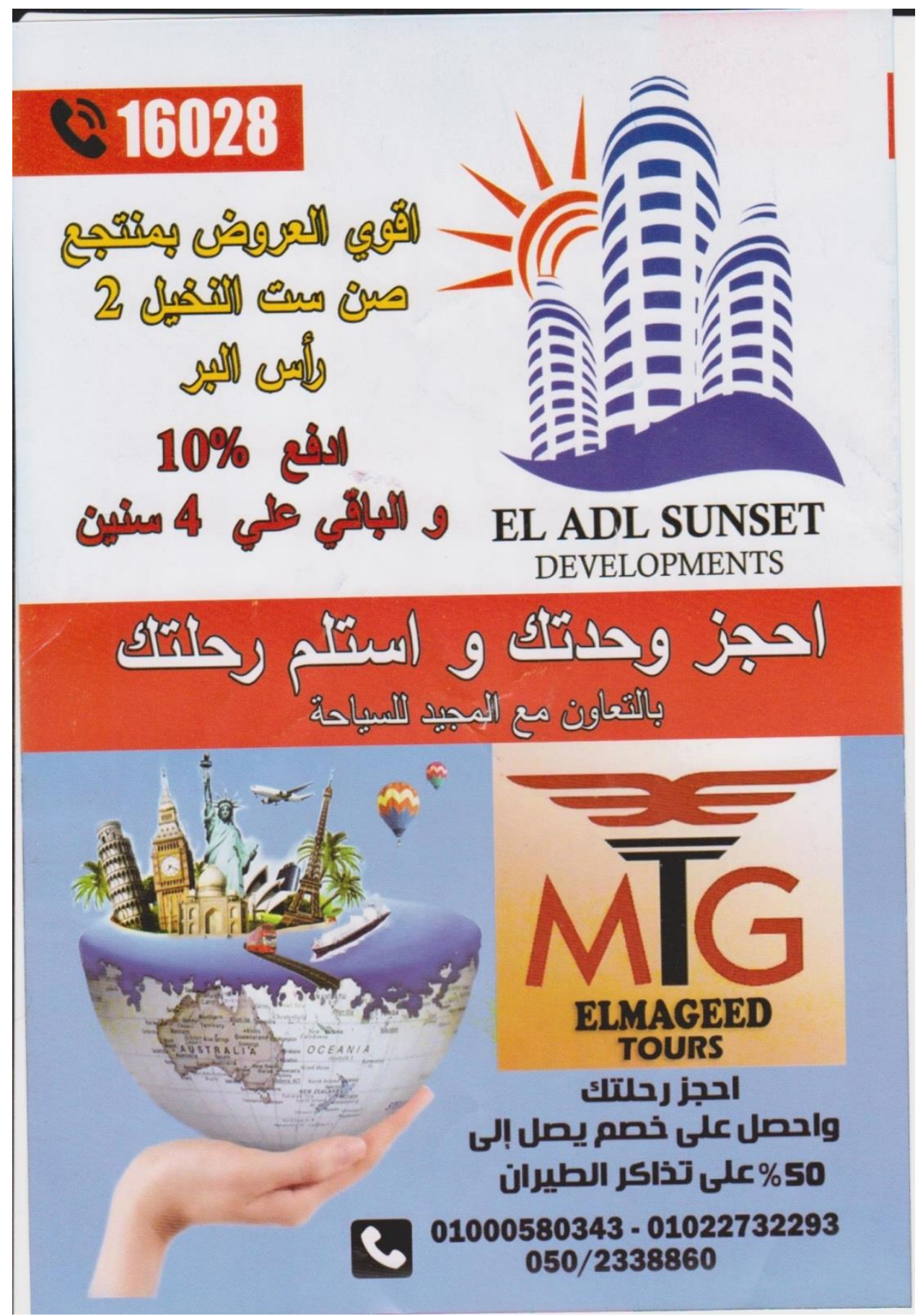




\section{References}

----- Alexander, Richard (1996). "Integrating the Ecological Perspective: Some Linguistic Self Reflexions." In: A. Fill (ed.) Sprachökologie und Ökolinguistik, Klagenfurt Symposion 27-28 October 1995, Tübingen: Stauffenberg, pp.131-148 ----- Armstrong, J. Scott. (2010). Persuasive Advertising: Evidence- based principles. Palgrave: Macmillan.

----- Austin, John Langshaw. (1962). How to do things with words. Boston: Harvard University Press.

Fakhry, Ahmad. (2012). The Pharaonic Egypt. Egypt: General Egyptian Book Organization.

----- Fill, Alwin. (1998). (Ecolinguistics - State of the Art 1998. AAA: Arbeiten aus Anglistik und Amerikanistik, 23 (1), 3-16

----- Fill, A, Mühlhäusler, P (eds) The Ecolinguistics Reader. London: Continuum, pp. 175-202

----- Gerbig, Andrea (1993). "The Representation of Agency and Control in Texts on the Environment." In: AILA '93, pp. 61-73.

----- Goddard, Angela, (1998). The language of Advertising. London and New York: Routledge.

Halliday, M. (1990). New ways of meaning: A challenge to applied linguistics.

Journal of Applied

Linguistics, 6, 7-36

Halliday, M. (1990). New ways of meaning: A challenge to applied linguistics.

Journal of Applied

Linguistics, 6, 7-36

Halliday, M.A.K., 1990. New ways of meaning. A challenge to applied linguistics. Journal of Applied Linguistics 6: 7-36

---- Hemdan, Gamal. (1967). Egypt Character (v 4). Dar Alhelal: Egypt.

Kravchenko, Alexander V. (2016). Language as human ecology: a new agenda for linguistic education. (42), pp. 14- 20.

---- Leech, Geoffrey N. English in advertising. London: Longman, 1966. Print.

----- Searle, John R. 1969. Speech Acts. Cambridge: Cambridge University Press

---- Weinrich, Harald. Halliday, MAK (1990). Economy and Ecology in

Language. In: Fill, A, Mühlhäusler, P (eds) The Ecolinguistics Reader. London:

Continuum, pp. 91-100 